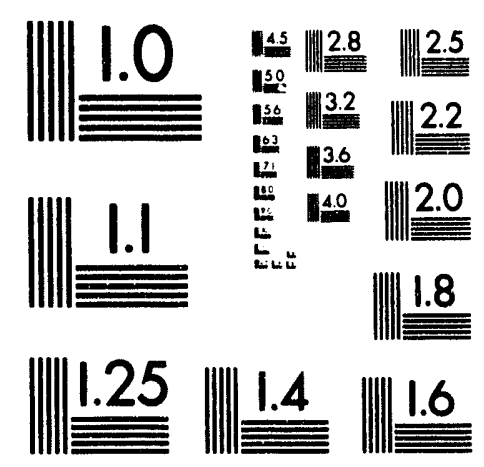



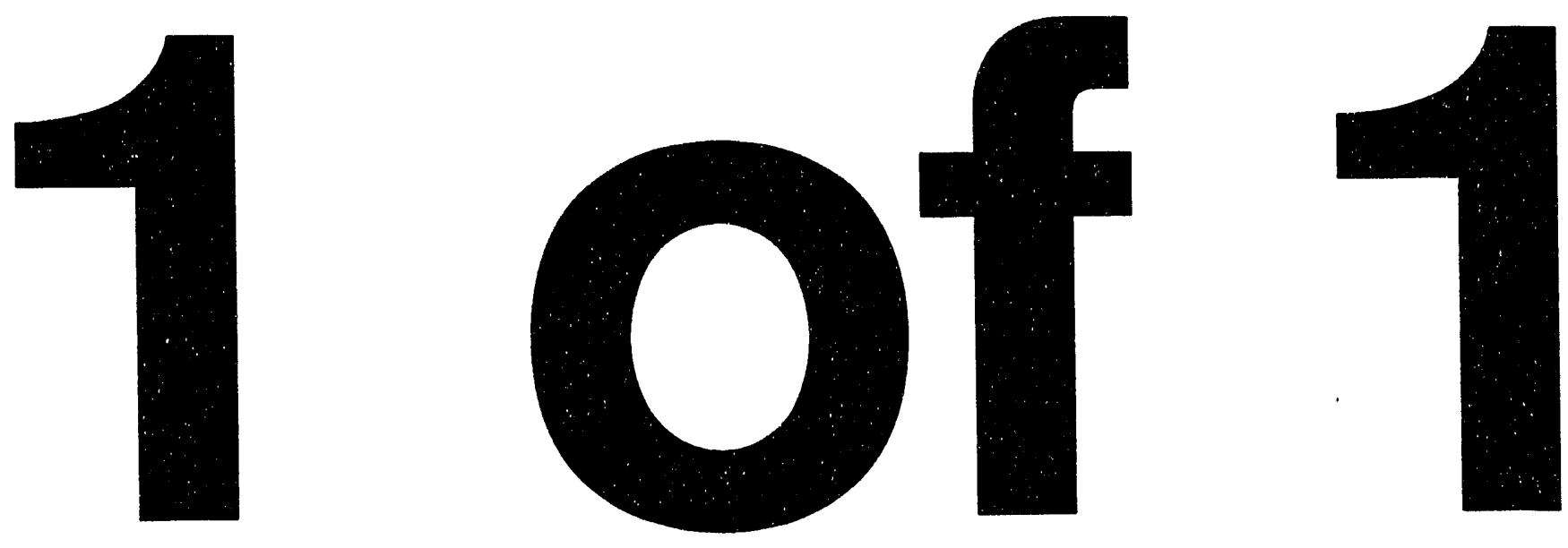
SAND93-7019

Distribution

Unlimited Release

Category UC-721

Printed June 1993

\title{
Properties of Salt-Saturated Concrete and Grout after Six Years In Situ at the Waste Isolation Pilot Plant
}

\author{
Lillian D. Wakeley, Patrick T. Harrington, and Charles A. Weiss, Jr. \\ Structures Laboratory \\ Waterways Experiment Station, Corps of Army Engineers \\ 3909 Halls Ferry Road \\ Vicksburg, MS 39180-6199*
}

\begin{abstract}
Samples of concrete and grout were recovered from short boreholes in the repository floor at the Waste Isolation Pilot Plant more than six years after the concrete and grout were placed. Plugs from the Plug Test Matrix of the Plugging and Sealing Program of Sandia National Laboratories were overcored to include a shell of host rock. The cores were analyzed at the Waterways Experiment Station to assess their condition after six years of service, having potentially been exposed to those aspects of their service environment (salt, brine, fracturing, anhydrite, etc.) that could cause deterioration.

Measured values of compressive strength and pulse velocity of both the grout and the concrete equaled or exceeded values from tests performed on laboratory-tested samples of the same mixtures at ages of one month to one year after casting. The phase assemblages had changed very little. Materials performed as intended and showed virtually no chemical or physical evidence of deterioration. The lowest values for strength and pulse velocity were measured for samples taken from the Disturbed Rock Zone, indicating the influence of cracking in this zone on the properties of enclosed seal materials.

There was evidence of movement of brine in the system. Crystalline phases containing magnesium, potassium, sulfate, and other ions had been deposited on free surfaces in fractures and pilot holes. There was a reaction rim in the anhydrite immediately surrounding each recovered borehole plug, suggesting interaction between grout or concrete and host rock. However, the chemical changes apparent in this reaction rim were not reflected in the chemical composition of the adjacent concrete or grout. The grout and concrete studied here showed no signs of the deterioration found to have occurred in some parts of the concrete liner of the Waste Isolation Pilot Plant waste handling shaft.
\end{abstract}

\footnotetext{
- This report was prepared by the Waterways Experiment Station for Sandia National Laboratories under contract AA 2030.
} 


\section{ACKNOWLEDGMENT}

The authors thank Dr. E. James Nowak, SNL, who was Project Manager when the work was initiated. It was completed under project management by Dr. Frank Hansen, SNL, for SNL Department 6121, of which Dr. Joe Tillerson is Manager. This report was reviewed by Drs. Jim Krumhansl and F. Hansen. The authors acknowledge the technical contributions of J. Pete Burkes, G. Sam Wong, and Joe G. Tom. 


\section{CONTENTS}

Introduction $\ldots \ldots \ldots \ldots \ldots \ldots \ldots \ldots \ldots \ldots \ldots \ldots \ldots \ldots \ldots \ldots \ldots$

Objectives of the Original Plug Test Matrix $\ldots \ldots \ldots \ldots \ldots \ldots$

Objectives of the 1991 PTM Recovery and Analyses $\ldots \ldots \ldots \ldots \ldots \ldots \ldots$

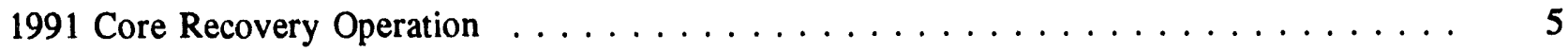

Physical Condition and Properties $\ldots \ldots \ldots \ldots \ldots \ldots \ldots \ldots$

Physical Property Testing $\ldots \ldots \ldots \ldots \ldots \ldots \ldots \ldots$

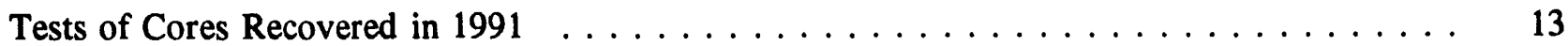

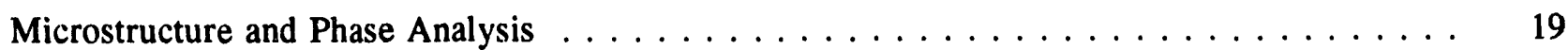

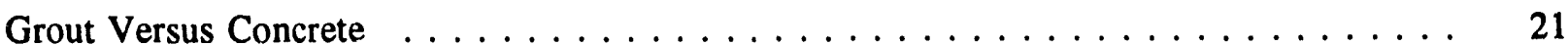

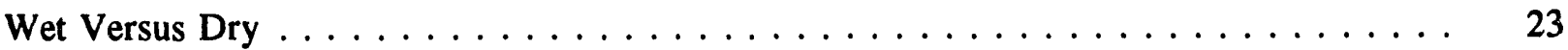

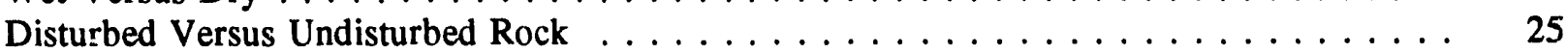

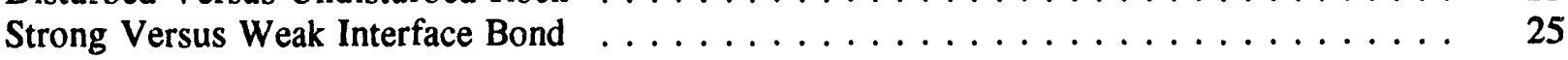

Discussion and Conclusions $\ldots \ldots \ldots \ldots \ldots \ldots \ldots$

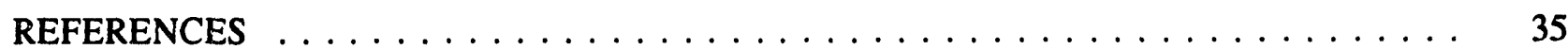

APPENDIX A: MIXTURE PROPORTIONS FOR GROUT AND CONCRETE AND GROUT PROPERTIES MEASURED DURING PREVIOUS RESEARCH . . . . . . A A-1

APPENDIX B: DATA FROM TESTS OF PHYSICAL PROPERTIES $1991 \ldots \ldots$. . . . B-1

APPENDIX C: PUSH-OUT RESISTANCE TEST METHOD $\ldots \ldots \ldots \ldots \ldots \ldots \ldots$

\section{Tables}

1. Expansive ESC Samples Associated with Brine on Recovery . . . . . . . . . . 7

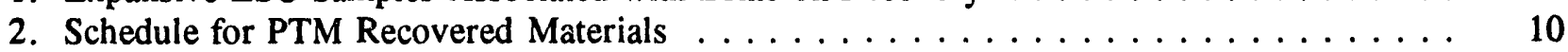

\section{Figures}

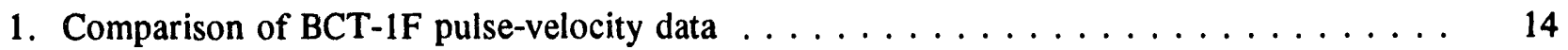

2. Comparison of ESC pulse-velocity data with Malhotra (1976) reference values . . . . . . . 14

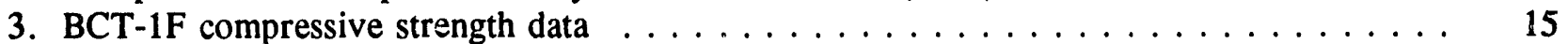

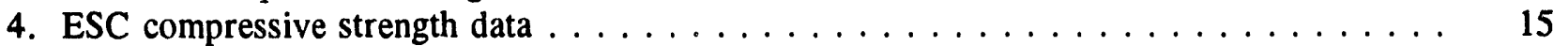

5. Push-out data for specimens tested in $1991 \ldots \ldots \ldots \ldots \ldots \ldots$ 


\section{Figures (Continued)}

6. Gypsum crystals growing out of pilot holes in concrete $\ldots \ldots \ldots \ldots \ldots$

7. Scanning electron secondary emission (left) and backscattered emission (right)

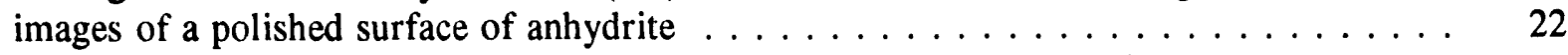

8. The concrete plug from the DRZ after push-out test, showing mineral-filled

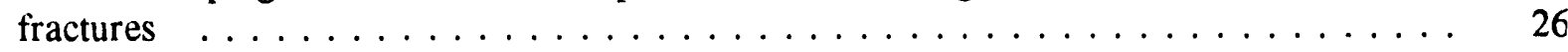

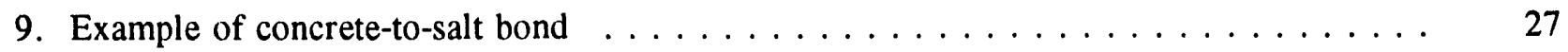

10. Concrete/halite core after push-out test, with breakthrough halite indicating strong bond between the salt and the concrete $\ldots \ldots \ldots \ldots$

11. Concrete/halite core from the undisturbed halite zone where failure occurred in the concrete . . . . . . . . . . . . . . . . . . . . . . . 29

12. Interface of grout and anhydrite with dark reaction ring in the anhydrite . . . . . . 30

13. Concrete/anhydrite core after push-out test. Note that failure occurred in the

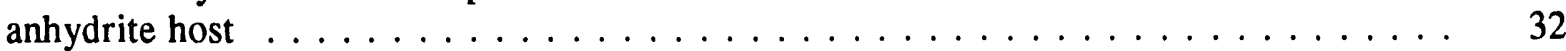




\section{INTRODUCTION}

The Waste Isolation Pilot Plant (WIPP) is a research and development facility of the US Department of Energy (DOE). Its purpose is to demonstrate the safe disposal of radioactive wastes resulting from US defense activities. The WIPP repository facility is located in bedded evaporite rock (principally halite), approximately $2,150 \mathrm{ft}(656 \mathrm{~m})$ below the ground surface, near Carlsbad, New Mexico.

For over 15 years, the US Army Engineer Waterways Experiment Station (WES), in cooperation with Sandia National Laboratories (SNL), has provided support in research and development of cement-based grouts and concretes for use in the WIPP repository facility. This support focused on the SNL Plugging and Sealing Program (PSP) to develop acceptable sealing technology at the WIPP based on a technical program, including laboratory materials research and verification and field testing (Stormont, 1984). "Sealing" specifically means creating a flow-restrictive barrier to prevent penetrations associated with boreholes, shafts, storage rooms, and accessways from becoming preferred pathways for waste transport after closure.

From 1984 through 1986, SNL performed a series of in situ experiments to evaluate the performance of various candidate seal materials. Field experiments included vertical and horizontal boreholes plugged with salt-saturated grout and concrete as part of the Small-Scale Seal Performance Tests (SSSPT) (Stormont, 1986). The WES formulated these candidate cement-based materials and performed supporting research.

\section{Objectives of the Original Plug Test Matrix}

A necessary part of the PSP not addressed by SSSPT was a requirement to assess the stability of candidate seal materials exposed to actual WIPP environments over time. This initiated the Plug Test Matrix (PTM) Test Plan prepared by Gulick (1984) with the purpose of measuring long-term effects on cement-based materials subjected to in situ conditions. Materials placed in boreholes located in the WIPP repository would undergo long-term (five and more years) exposure to physical and chemical conditions of the repository environment. As initially planned, hardened and appropriately aged specimens from the PTM were to be removed at intervals and assessed for physical properties and chemical stabiiity. 
Candidate cement-based mixtures formulated for the SSSPT were placed in the WIPP in 1984 and 1985. A saltwater grout (BCT-1F) was developed in 1979 as a result of extensive work by the WES and others in support of the Bell Canyon Test (BCT) for cement grouts (Gulick et al., 1980). Formulation of cementitious material placed in the PTM in late 1984 was essentially the original formulation of BCT-1F grout. Field-cast specimens were prepared and tested at the WES. An expansive salt-saturated concrete (ESC) was also developed at the WES during 1985 (Wakeley and Walley, 1986) and placed in test series A and B of the SSSPT (Stormont, 1986). Field specimens cast during these placements of ESC were studied at the WES, more extensively than were specimens from previous placements. Some of these data were reported previously (Comes et al., 1987). Summaries of grout and concrete development for the WIPP, including WES field and laboratory support to SNL, have also been published (Wakeley and Walley, 1986; Wakeley, 1987; Wakeley and Poole, 1986; Wakeley and Poole, 1987; Gulick and Wakeley, 1989).

As best-candidate mixtures at that time, these materials were emplaced in small-diameter vertical boreholes in the PTM. The PTM consisted of 24 boreholes, each having a $12-\mathrm{ft}$ vertical depth. These boreholes were located in Room L1 of the WIPP repository in two rows parallel to the north wall. The first row consisted of 12 holes, approximately 36 in. apart, each with a 2 -in. nominal diameter. The second row, approximately 36 in. behind the first row, consisted of another 12 holes, with a 4-in. nominal diameter. The first row of holes $(2$ in.) was plugged in 1984 with WES-formulated BCT-1F grout; the second row of holes (4 in.) was plugged in 1985 with WES-formulated ESC during the field activity of placing ESC in the vertical boreholes of the SSSPT. Some of these data were reported previously (Comes et al., 1987).

As described in the original 1984 SNL Test Plan, objectives of the PTM were to:

- Develop emplacement techniques for primary candidate plug materials.

- Provide long-term in situ specimens of candidate plug materials for periodic removal and evaluation of plug properties.

- Expand plug performance data base.

- Verify existing laboratory data from candidate cement-based materials. 
Because of changes in priorities, PTM specimens were not recovered or analyzed at the intended intervals. Other than a few portions of plugs recovered in 1985, no samples from the PTM were recovered or analyzed until 1991. By that time, performance criteria for cement-based materials had changed, and BCT-1F and ESC were no longer the leading candidate grout and concrete, respectively.

Discovery of deteriorated concrete in the waste-handling shaft at the WIPP in spring of 1990 led to an extensive research effort to determine the causes of observed deterioration of the concrete of the shaft liner, which was close in age to the SSSPT concrete. Following analysis at the WES and elsewhere of samples of deteriorated concrete recovered from the waste-shaft liner in 1990 (Wakeley et al., 1992; Nowak et al., 1993), it was clear that assessing the condition of concretes that had been in service for roughly the same length of time as the waste-shaft liner would provide data important to understanding the serviceability of concretes in this difficult environment.

The service environments of the waste-shaft liner and the PTM were not directly comparable. Brines in the environments of the waste-shaft liner and the PTM plugs probably were from different sources. There was evident continuous flow of brine at the waste shaft liner. The ratio of potassium to magnesium in seepage brines in the shaft indicated that brines collected there were derived from the contact between the Rustler and Salado Formations (Lambert et al., 1992). Brines available to the PTM were more likely to have been derived from the enclosing rocks at the WIPP storage horizon. The PTM brines were probably more representative of the environment in which concrete-seal components will be placed. Because of this probable difference in source, the chemical compositions and quantity of fluids available to react with the concretes were different, and the materials had not been exposed to identical hazards. However, given the possibility of concrete deterioration in contact with any Mg-bearing fluid, it was important to determine the condition of the PTM plugs.

The original composition and physical properties of the grout and concrete in the PTM had been documented to study any alteration from the original condition. If the PTM grout or concrete were deteriorated to a degree similar of the waste-shaft concrete at the joint between liner and keyway, then significant concerns would obviously exist regarding use of concrete in the seal system. Conversely, if the PTM plugs retained their original composition and properties, they would provide a well documented example of acceptable concrete performance underground at the WIPP. 


\section{Objectives of the 1991 PTM Recovery and Analysis}

This report documents the recovery and analysis in 1991 of sections of PTM borehole plugs and enclosing rock, approximately six years after placement. This report will address two of the original PTM objectives, with specific emphasis on:

- Assessing indications of long-term performance of original WES-formulated cementbased materials;

- Identifying evidence of any active chemical processes that have affected these materials.;

- Comparing properties of recently recovered PTM materials to those of laboratory- and field-cast specimens of the materials as originally placed and to other reference properties;

- Providing input to decisions made in the ongoing plocess of refining candidate cementbased materials for the WIPP seal system.

Durability itself is not a measurable property of concrete. Assessing durability is an assessment of performance of a specific concrete in its service environment over time. This being the intent of the PTM, in 1991 four of the PTM borehole plugs were removed and transported to the WES for petrographic analyses and evaluation of physical properties. The following section describes recovery operations. Subsequent sections describe physical testing and assessment of chemical stability. 


\section{CORE RECOVERY OPERATION}

Two BCT-1F grout plugs and two ESC concrete plugs. and their enclosing host rock were overcored between 14 and 23 May 1991 and shipped to the WES for study. This involved a joint effort of SNL, Westinghouse Corp., and other contractors with WES personnel participating between 14 and 17 May. Overcores were taken at twice the actual plugged diameter to preserve the integrity of the host rock and plug interface, and also to minimize the disturbance to the plug. The recovery plan was documented in WES Research Project Plan 91-13(B).

The 12-ft length of grout and concrete plugs extended through three distinct rock zones beneath the repository floor. From the repository floor to depths of approximately 4 to $5 \mathrm{ft}$, the host-rock material was primarily halite. The surface layer of halite is within the disturbed rock zone (DRZ), defined as the zone of rock in which the mechanical and hydrologic properties have changed in response to excavation (Borns and Stormont, 1989). The anhydrite seam also within the DRZ, called Marker Bed 139 (MB139), lies approximately 5 to $8 \mathrm{ft}$ below the floor surface. Below this depth, halite again was the predominant rock. A layer of up to $2 \mathrm{ft}$ of mixed mineralogy was present at the interface of anhydrite and halite. As documented elsewhere (Borns and Stormont, 1989), the DRZ including MB139 experienced movement and severe fracturing over time. The lower layer of halite was relatively unaffected by movement with significantly less fracturing over time.

The first two holes overcored were from the first PTM row. These were overcored using a 4-in.-inside-diameter core barrel around a 2-in.-diameter BCT-1F grout plug. The first hole, L1S02, was completed by $1500 \mathrm{hrs}$ of day one. Approximately 5 hours of continuous work were required to recover $12 \mathrm{ft}$ of material from this hole. Recovered material had multiple horizontal fractures, with a distance between fractures varying from 0.25 to 3.00 in. Some depths yielded extensively broken core fragments (rubble). This phenomenon was common in the DRZ and MB139 seam. Once drilling passed through the anhydrite seam into the undisturbed salt, the remaining material was recovered in more continuous lengths (approximately 0.5 to $2.0 \mathrm{ft}$ ).

Overcoring of L1S02 resulted in recovery of rubble and in some instances lost material. On-site personnel judged that lost material was attributable to jamming of cut material eccentrically in the core barrel, which then would grind the remaining length of the coring run. Although this would have produced large volumes of finely ground rock, it went unnoticed because the vacuum hose system for dust control directly removed all finely ground material from the hole. Overall, core 
recovery from L1S02 was not completely successful because of some lost intervals and excessive fracturing.

The second hole overcored was BCT-1F plug hole L1S01, immediately adjacent to L1S02. Again in the DRZ and MB139, recovered material experienced extensive horizontal fracturing. Also, cores were recovered as rubble at certain depths. However, loss of core was minimized because during the cutting procedure, the crew took steps to ensure that the core-barrel rotational speed was kept to a minimum. Also the dust coming from the hole under vacuum pressure was checked continually for evidence of increased volume or changes in particle size.

ESC material was recovered with better results. The same procedures were used as with the BCT-1F plugs, except an 8-in.-inside-diameter core barrel was used to recover 4-in.-diameter plugs. Recovered ESC plug holes were L1S13 and L1S14 (Appendix B). Recovered overcore lengths varied from 6 to approximately 36 in. Minimal rubble material was recovered with L1S14. Although overall recovery of ESC and host-rock material proceeded better than that experienced with grout plugs, other problems occurred that resulted in longer recovery time per hole.

During overcoring of ESC holes, the presence of brine was evident at certain locations. Table 1 tabulates information on hole, wet/dry condition, and rock type. Due to the presence of brine in the borehole, overcoring took longer because the core barrel cutting-teeth experienced a buildup of pastelike material. This was apparently a mixture of brine and powder from cut material. Also, removal of cut material from the borehole was more difficult for these depths. No brine accumulations had been noted during recovery of the BCT-1F grout plugs, so it was not possible to recover brine from holes drilled during this operation. Grout holes were dry during recovery and were observed by WES personnel to have remained dry 48 hours thereafter. Open holes nearby were at least partly filled with fluid, which onsite personnel attributed to human activity, including brine sprayed for dust control. 
Table 1. Expansive ESC Samples Associated with Brine on Recovery

\begin{tabular}{|c|c|c|c|}
\hline$\underline{\text { Recovered Sample }}$ & Hole Depth & Condition & Rock Zone \\
\hline L1S13 - No. 1 & 0.58 to $2.88 \mathrm{ft}$. & Wet & DRZ \\
\hline L1S13 - No.2 & 2.88 to $5.38 \mathrm{ft}$. & Wet & DRZ/MB139 \\
\hline L1S13 - No. 5 & 9.92 to $11.67 \mathrm{ft}$. & Wet & Halite below MB139 \\
\hline L1S14 - No. 2 & 2.25 to $4.25 \mathrm{ft}$. & Wet & DRZ \\
\hline
\end{tabular}

Repository room temperatures, relative humidity, and core temperatures were measured during overcoring and core recovery. Room temperatures ranged from 80 to $83^{\circ} \mathrm{F}$, and relative humidity measurements ranged from 18 to 31 percent. Immediately after removal from boreholes, core temperatures measured approximately $90^{\circ} \mathrm{F}$. Based on core surface temperature measurements after removal from holes, core temperatures during barrel cutting was estimated to have been $\geq 100^{\circ} \mathrm{F}$. This was a concern because of the potential for heat to alter the phase composition of cement-based materials.

Recovered materials were then prepared and shipped to the WES under the supervision of SNL representatives at the WIPP site. Materials were wrapped in plastic then boxed and crated while underground at the WIPP facility. SNL quality assurance forms were used to document shipping and receiving. Overcoring was completed on 23 May, and materials were received at the WES on 6 June 1991.

Materials received at the WES arrived in poor condition because they were inadequately packaged at the WIPP site before shipping. The plastic film used to wrap core segments and intended to seal them from each other and from environmental exposure was open and torn. This caused samples to be exposed to unknown conditions during shipping and allowed physical mixing of some materials where rubble had been recovered. Some core segments had been broken; all core fragments of questionable identity were discarded. This limited our ability to reconstruct core lengths and conduct initial visual examinations and decreased the number of samples available for testing. 


\section{PHYSICAL CONDITION AND PROPERTIES}

All core samples recovered in 1991 were examined visually in the as-received condition. Condition of cores and fracture surfaces was noted. Specimens of each core were identified for specific tests and analyses based on the relative length of the sample and its physical condition. Specimens selected were from the surface, DRZ, MB139, and from material representing wet and dry conditions when recovered. Tests selected for assessing physical properties are shown in Table 2, with core intervals assigned to each test type. Materials were also scheduled for petrographic examination. The purpose of all analyses was to assess the long-term stability of these materials after extended exposure to WIPP repository conditions. 
Table 2. Schedule for PTM Recovered Materials

\begin{tabular}{|c|c|c|c|}
\hline \multirow[b]{2}{*}{ Sample } & \multicolumn{3}{|c|}{ Physical Property Analyses } \\
\hline & $\begin{array}{c}\text { Pulse } \\
\text { Velocity }\end{array}$ & $\begin{array}{l}\text { Compressive } \\
\text { Strength } \\
\end{array}$ & $\begin{array}{c}\text { Push-Out } \\
\text { (Shear) }\end{array}$ \\
\hline \multicolumn{4}{|l|}{ BCT-1F: } \\
\hline \multicolumn{4}{|l|}{ L1SO1 - No. 6} \\
\hline 8.17 to $9.08 \mathrm{ft}$. & $\checkmark$ & & $\checkmark$ \\
\hline 9.17 to $9.83 \mathrm{ft}$. & $\checkmark$ & $\checkmark$ & \\
\hline 9.83 to $10.58 \mathrm{ft}$. & $\checkmark$ & & $\checkmark$ \\
\hline \multicolumn{4}{|l|}{$\mathrm{L} 1 \mathrm{SO}_{2}-\mathrm{No} \cdot 1$} \\
\hline 0.00 to $0.33 \mathrm{ft}$. & $\checkmark$ & & $\checkmark$ \\
\hline 1.00 to $1.25 \mathrm{ft}$. & $\checkmark$ & $\checkmark$ & \\
\hline 1.58 to $1.83 \mathrm{ft}$. & $\checkmark$ & & $\checkmark$ \\
\hline \multicolumn{4}{|l|}{ L1SO2 - No. 3} \\
\hline 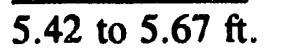 & $\checkmark$ & $\checkmark$ & \\
\hline 6.67 to $7.17 \mathrm{ft}$. & $\checkmark$ & & $\checkmark$ \\
\hline \multicolumn{4}{|l|}{ ESC: } \\
\hline \multicolumn{4}{|l|}{ L1S13 - No. 1} \\
\hline 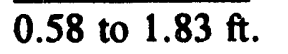 & $\checkmark$ & & $\checkmark$ \\
\hline 1.83 to $2.88 \mathrm{ft}$. & $\checkmark$ & $\checkmark$ & \\
\hline \multicolumn{4}{|l|}{$\underline{L 1 S 13}-\mathrm{No}, 3$} \\
\hline 6.38 to $7.50 \mathrm{ft}$. & $\checkmark$ & $\checkmark$ & \\
\hline \multicolumn{4}{|l|}{$\underline{\mathrm{L}} \mathrm{S} 13-\mathrm{No} .4$} \\
\hline 7.67 to $8.50 \mathrm{ft}$. & $\checkmark$ & & $\checkmark$ \\
\hline 8.58 to $9.92 \mathrm{ft}$. & $\checkmark$ & $\checkmark$ & \\
\hline \multicolumn{4}{|l|}{ L1S14 - No. 2} \\
\hline 2.25 to $2.88 \mathrm{ft}$ & $\mathcal{L}$ & & $\mathscr{L}$ \\
\hline 2.88 to $3.50 \mathrm{ft}$. & $\checkmark$ & $\checkmark$ & \\
\hline \multicolumn{4}{|l|}{ L1S14 - No. 4} \\
\hline 6.50 to $7.42 \mathrm{ft}$ & $\checkmark$ & & $\checkmark$ \\
\hline \multicolumn{4}{|l|}{$\underline{\text { LIS14 } 14-\mathrm{No} .5}$} \\
\hline 7.83 to $9.00 \mathrm{ft}$. & 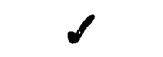 & $\checkmark$ & \\
\hline
\end{tabular}




\section{PHYSICAL PROPERTY TESTING}

Samples outlined in Table 1 were prepared for pulse velocity, compressive strength, and pushout testing. Pulse velocity and compressive strength testing followed standard American Society for Testing and Materials (ASTM) procedures C 597-83 Standard Test Method for Pulse Velocity Through Concrete and C 39-86 Standard Test Method for Compressive Strength of Cylindrical Concrete Specimens (American Society for Testing and Materials, 1991). These tests were conducted to assess the relative quality of cement-based specimens as compared to similar data generated from specimens cast during original placements.

Placement of BCT-1F material occurred in 1984 with testing of field-cast specimens in 1984 and 1987. These data from tests of BCT-1F have not been published before, although the purpose of the field activities and some test data have been published (Wakeley, 1987; Gulick and Wakeley, 1989). Specimens were cast in the field in both plastic and steel molds, representing unrestrained and restrained conditions, respectively. Original mixture proportions for this grout are in Appendix A.

Placement of ESC occurred in 1985 with testing of field-cast specimens for compressive strength and other physical properties occurring periodically at the WES for up to one year. Some of these data were analyzed and published previously (Comes et al., 1987). Pulse velocity measurements were not conducted as part of that ESC test program. Mixture proportions for the field-cast ESC as reported by Wakeley and Walley (1986) are in Appendix A. 


\section{TESTS OF CORES RECOVERED IN 1991}

Pulse velocity tests were conducted on each sample identified for physical property testing (Table 2). Data for dynamic modulus of elasticity exist for both ESC and BCT-1F field-cast specimens. But this property was not measured on recovered cores because individual samples were too small. Data from individual tests of pulse velocity and other properties for recovered cores are tabulated in Appendix B. Data for specimens cast during original placements of BCT-1F are tabulated in Appendix A.

Data from tests of pulse velocity for BCT-1F grout, as measured for the plugs recovered in 1991, are compared to data from similar tests of grout specimens cast at the same time and tested in 1984 (initial) and 1987 (Figure 1). Comparison of current ESC data with pulse velocity values published for concrete (Malhotra, 1976) is shown in Figure 2. Specimens were prepared for tests of compressive strength from both ESC and BCT-1F cores recovered in 1991. ESC specimens were prepared by removing 2-by-4-in. concrete cores from the center of the original 8-in.-diameter recovered cores. Samples L1S14 - No.2 (2.88 to $3.50 \mathrm{ft}$.) and - No.5 (7.83 to $9.00 \mathrm{ft}$.) were not tested as planned because problems occurred while attempting to retrieve inner cores. Inner cores were not necessary in preparation of BCT-1F specimens for tests of compressive strength. Measured strength values of specimens with length-to-diameter $(\mathrm{L} / \mathrm{D})$ ratios less than 1.8 were corrected as indicated in ASTM C 42. Data from these tests are presented in Appendix C.

Data from tests of field-cast ESC cylinders were published previously (Comes et al., 1987) and are not repeated here. Data from tests of BCT-1F field-cast cylinders are presented in Appendix A. Comparison of strength data for BCT-1F is shown in Figure 3. Values from 1984 are from field-cast samples at 104 days of age. The lower values from 1987 were from samples cast and stored in steel molds, many of which fractured when the molds were removed. Higher values from 1987 tests were from samples cast and stored in plastic molds. These experienced less stress relief when molds were removed, resulting in less fracturing and higher measured strengths. Strength values from 1991 tests are higher than either average value from 1987. In Figure 4, data from tests of field-cast samples of ESC are compared to data from PTM samples recovered and tested in 1991. Again, 1991 values from samples that had spent six years in the underground at the WIPP are higher. 


\section{BCT-1F Materials}

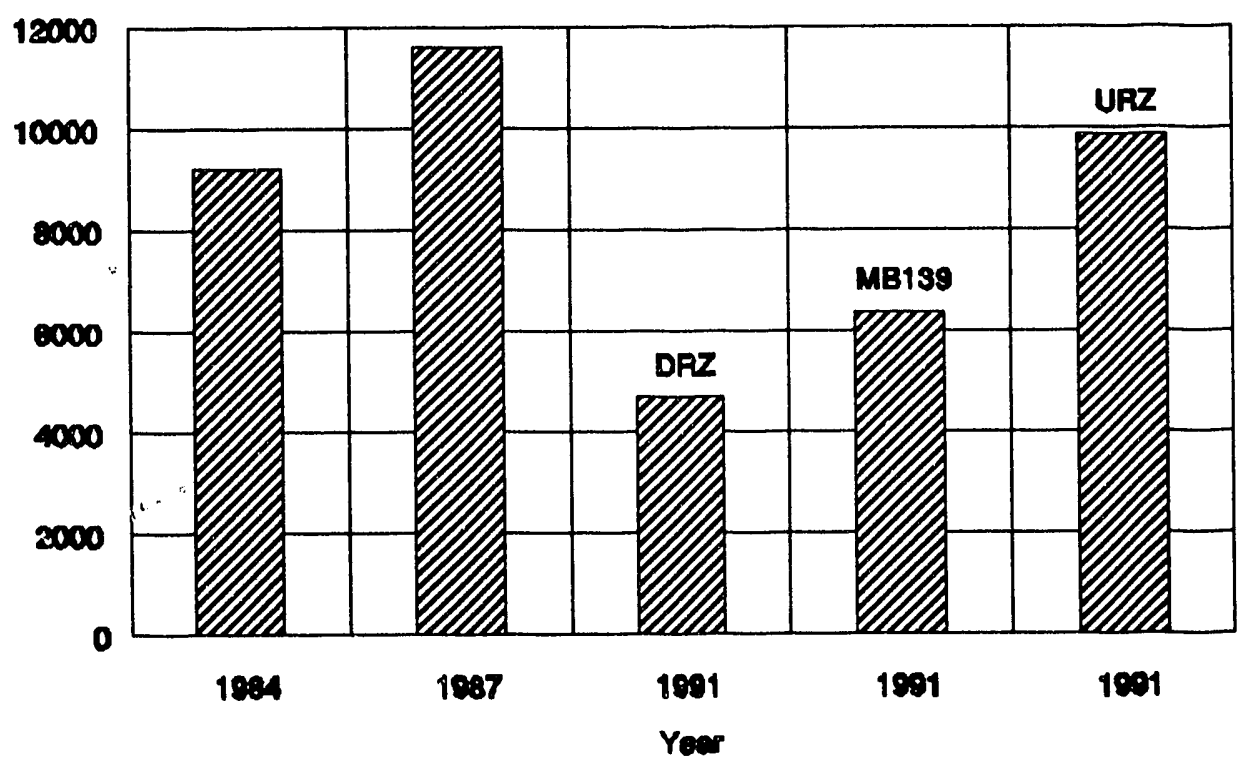

Figure 1. Comparison of BCT-1F pulse-velocity data.

\section{ESC Materials}

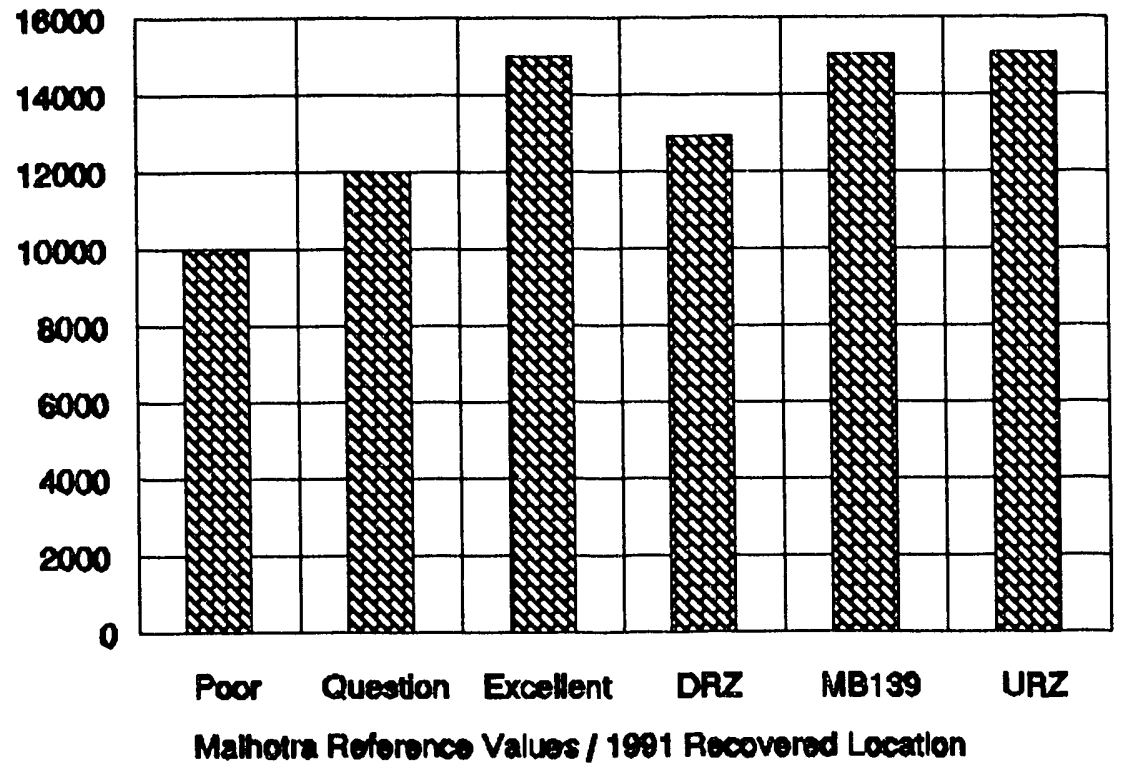

Figure 2. Comparison of ESC pulse-velocity data with Malhotra (1976) reference values. 


\section{BCT-1F Materials}

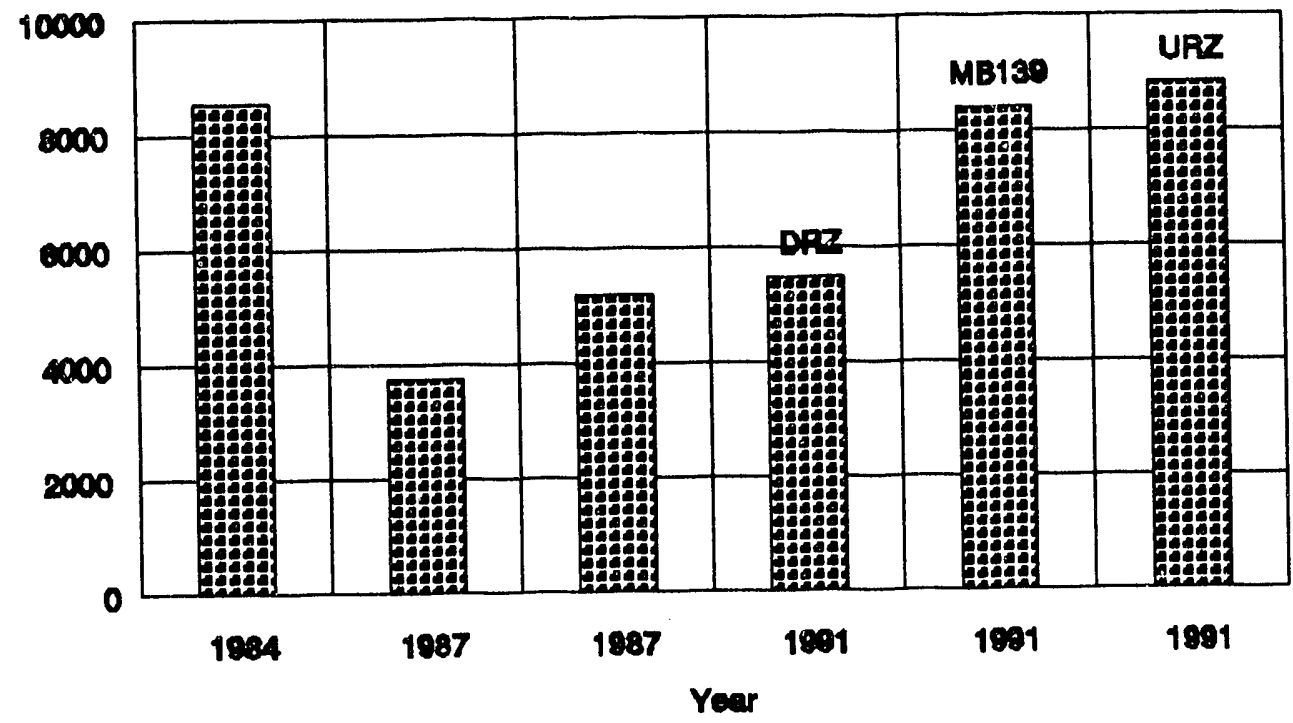

Figure 3. BCT-1F compressive strength data.

ESC Matorials

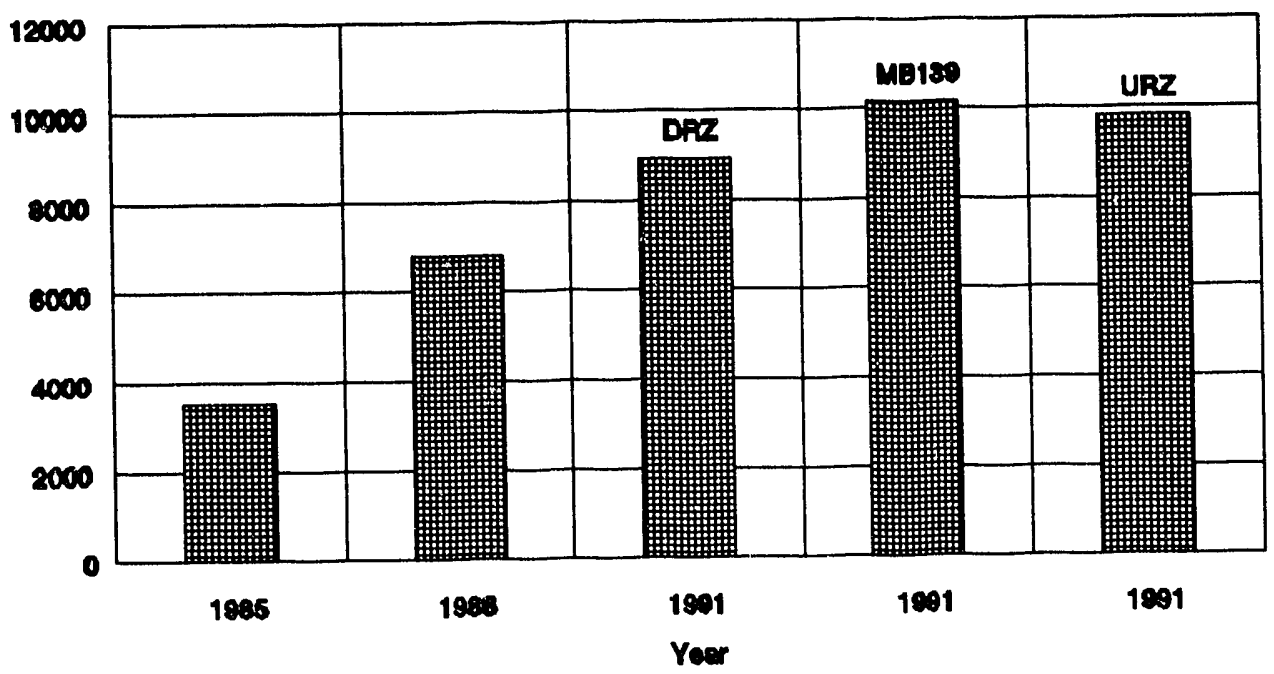

Figure 4. ESC compressive strength data. 
Push-out tests were conducted to help assess the performance of each cement-based material in the vicinity of the host-rock interface. Previous similar push-out tests were conducted by others (Roy et al., 1985; Akgun and Daemen, 1991). There are uncontrollable factors associated with the pushout testing, such as eccentricity of the plug segment in the total core, an unavoidable condition in overcoring operations. Therefore, the test does not necessarily measure interface bond strength. In cases where the plug supposedly being pushed out is not parallel to the overcore, the supposed "bond strength" may actually be a measure of the strength of the rock.

Another factor that makes bond-strength values inconsistent includes microfractures induced at and around the interface during core recovery. However, if a cement-based material is going to undergo chemical attack, it is most likely to do so at the interface of plug and host rock. So the presence of a secure bond at these interfaces is a good indicator of the concrete performance. When the samples were received at the WES, initial observations of interfaces showed no evidence of plug/rock interaction for samples in rock salt, although there was an apparent reaction on rim in anhydrite. Physical descriptions of these interfaces are presented elsewhere.

The fact that all plug/rock interfaces remained intact during coring, core recovery, shipping, and subsequent sawing and subsampling shows the generally excellent condition of the plug/rock interfaces and favorable performance and durability of these materials after more than six years of exposure to the WIPP environment. Appendix B presents test results for both BCT-1F and ESC plugs; Appendix $\mathrm{C}$ provides a description of the test method used for push-out testing. Figure 5 summarizes push-out data on specimens recovered from the WIPP. 


\section{Push-Out Data 1991}

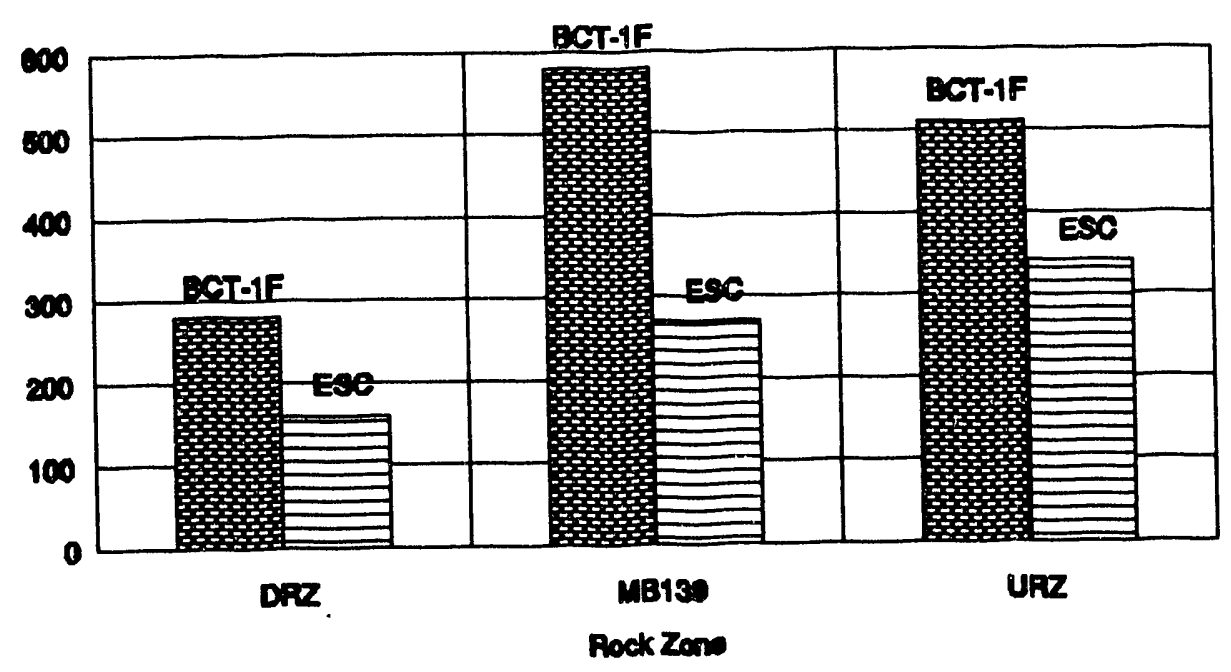

Figure 5. Push-out data for specimens tested in 1991. 


\section{MICROSTRUCTURE AND PHASE ANALYSIS}

The comparison of data from earlier test results on physical properties of the grout and concrete to those generated during the recent study was straightforward. For data from phase composition and microstructure, it was difficult to compare old data-those from samples cast in molds at the time of PTM placements or recovered soon after-to data from samples recovered from the WIPP site during 1991. The technology of analyses had changed. Both the old and new data represent many variables that can change some aspect of microstructure without having a gross impact on physical properties. The stable phase assemblage present in a hydrated cement can be changed notably by temperature and humidity. Old samples had been stored at various temperatures and humidities, none of which was the same as that of the repository. If differences were observed, the source might not be obvious. Compressive strengths increased from initial conditions instead of decreasing, indicating that if chemical changes had occurred, they had not reduced the strength of the grout or concrete.

There is some uncertainty about the variability of the environment into which the PTM plugs were placed. Brines or other fluids could have been introduced during in situ permeability tests or spraying for dust control. Such fluids introduced to the DRZ could have affected a large volume of rock and possibly the test plugs. However, these events occurred five or more years ago. Although it is likely that the plugs could have been exposed to brines of an unknown composition early in their history, it is also likely that brines present now and for some time in the past represent the natural brines of the enclosing strata.

As stated earlier, only four intervals of concrete core were visibly wet when recovered, and none of the holes accumulated a noticeable amount of fluid in the few days after the 1991 drilling. Three of the wet intervals were in the DRZ, and the fourth was in the halite below the marker bed. However, virtually all concrete core segments were wet during their time in situ. Evidence for this is the presence of crystalline material in cracks, pilot holes (Figure 6), and all free surfaces, consisting of several minerals related chemically to the host rocks.

None of the intervals of grout core was visibly wet when recovered, and there were no open holes within the plugs. However, crystalline compounds had accumulated on surfaces of fractures through the grout and associated with fractures or distinct crystalline stringers in the enclosing rocks. As in the concrete, the mineral accumulations in all intervals of grout were $\mathrm{Mg}$-bearing compounds, such as polyhalite, magnesite, and sulfates. The minerals in certain intervals are listed in the 


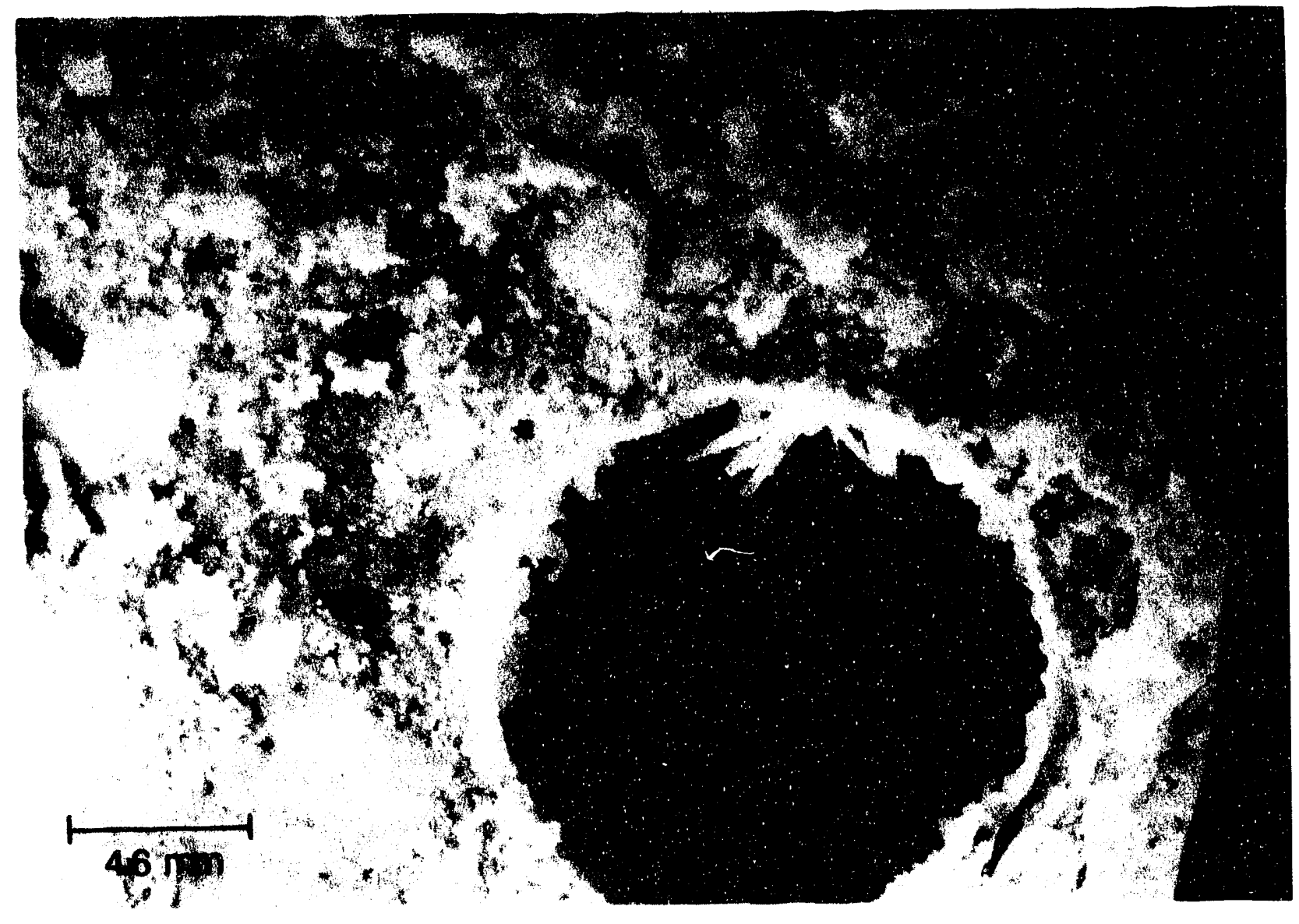

Figure 6. Gypsum crystals growing out of pilot holes in concrete. 
discussions of phase composition and microstructure in the following sections. Magnesite as an accessory mineral to the anhydrite of MB139 is shown in Figure 7, demonstrating the presence of magnesium in the host rock.

As described previously, the recovered core segments represent three different rock zones with different mineral composition and extent of fracturing. Because some intervals of concrete core were wet when recovered, it was possible to compare wet versus dry intervals. Locations of original holes and of recovered plugs were chosen for physical convenience rather than systematically to represent wet or dry conditions at the time the holes were plugged. There also are two materials (grout and concrete) with different porosities, densities, aggregates, and composition of cementitious materials. The number of samples representing any one set of conditions was small, precluding any statistical analyses of data to delineate controlling variables.

We compared phase assemblages and physical appearance of grout or concrete samples by pairs, emphasizing comparisons of wet versus dry cores and of those from the DRZ versus an undisturbed condition. The following paragraphs describe these comparison pairs based on observations from petrographic studies including phase composition and microstructure. Core intervals are given for each pair of cores cited as an example of each condition by field-core number, WES core number, and depth.

\section{Grout Versus Concrete}

Previous work on the composition of grout samples (BCT-1F) by $\mathrm{x}$-ray diffraction (XRD) analysis determined that the grout characteristically contained calcium chloro-aluminate hydrate $\left[\mathrm{Ca}_{2} \mathrm{Al}(\mathrm{OH})_{6}\right]\left[\mathrm{Cl} \cdot 2 \mathrm{H}_{2} \mathrm{O}\right]$, ettringite $\left\{\mathrm{Ca}_{6}\left[\mathrm{Al}(\mathrm{OH})_{6}\right]_{2} \cdot 24 \mathrm{H}_{2} \mathrm{O}\right\}\left[\left(\mathrm{SO}_{4}\right)_{3} \cdot 1-1 / 2 \mathrm{H}_{2} \mathrm{O}\right]$, and portlandcement phases for ages from 48 days to 32 months after casting. Phase composition of concrete (ESC) was not followed closely after field placement because the material had not been formulated for geochemical stability, and the need to follow chemical changes was not a recognized part of the work under way at the time. Given its component materials, we surmise that its composition was similar to the grout samples. 

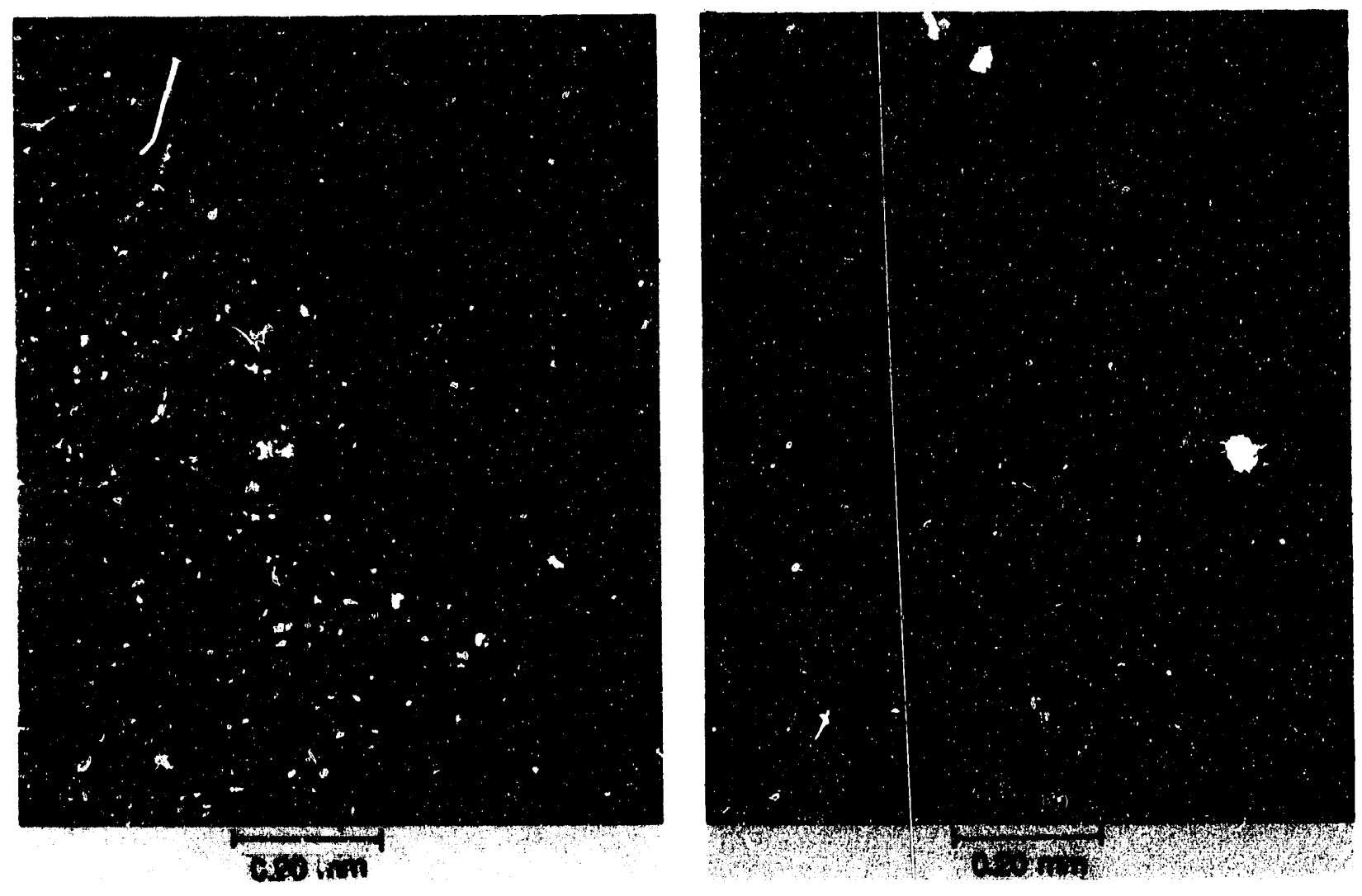

Figure 7. Scanning electron secondary emission (left) and backscattered emission (right) images of a polished surface of anhydrite. 
The grout and concrete taken from the 1991 cores were analyzed by XRD. The only compositional differences identified were attributable to the different aggregates used in the grout (primarily quartz sand) compared to that of the concrete (dolomite, calcite, and quartz). No major differences in phase composition were observed for grout samples taken at different depth intervals or from different host rocks. The phase composition of all grout samples taken from cores was the same as that determined previously, except that ettringite was absent in the 6-year-old grout and anhydrite was observed in samples recovered from the anhydrite zone.

As with the grout samples, all XRD patterns of 1991 concrete have the same phases and in similar proportions, regardless of depth interval. These phases include dolomite $\left[\mathrm{CaMg}\left(\mathrm{CO}_{3}\right)_{2}\right]$, calcite $\left[\mathrm{CaCO}_{3}\right]$, quartz, ettringite, calcium chloro-aluminate hydrate, and halite.

\section{Wet Versus Dry}

Sections of concrete core samples identified as recovered from wet zones all had the same phaser, and in similar proportions, as determined by XRD. As noted above, these phases included dolomite, calcite, quartz, ettringite, calcium chloro-aluminate hydrate, and halite. Furthermore, the phases present in these concretes at the contact with halite are the same as those in the center of each core, away from the interface or other discontinuities. This indicates that there is no influence on phase composition of the concrete by contact with salt and an apparently stable phase assemblage.

Phases observed in pilot holes in the concrete recovered wet included halite, brucite $\left[\mathrm{Mg}(\mathrm{OH})_{2}\right]$, and sylvite $[\mathrm{KCl}]$. There was a large proportion of an apparently amorphous phase present in these locations. Other phases found were well formed gypsum $\left[\mathrm{CaSO}_{4} \cdot 2 \mathrm{H}_{2} \mathrm{O}\right]$ crystals extending out from the wall of the hole into the void (Figure 6).

Concrete samples recovered in dry salt were virtually identical to those recovered wet. The phase assemblages close to the salt contact were indistinguishable by XRD from those in the centers of the cores. Concrete samples recovered in contact with anhydrite included the same phases found in the concretes recovered both wet and dry, as determined by XRD.

Crystallization of various minerals, such as gypsum, also occurred in the concrete samples recovered in a dry condition. The host rock contains the phases found in the fractures in the 
concrete. In addition to halite and gypsum, other phases present in the halite host rock included calcite, dolomite, anhydrite, and quartz. An XRD of a seam in the host halite revealed the presence of polyhalite $\left[\mathrm{K}_{2} \mathrm{Ca}_{2} \mathrm{Mg}\left(\mathrm{SO}_{4}\right)_{4} \cdot 2 \mathrm{H}_{2} \mathrm{O}\right]$, magnesite $\left[\mathrm{MgCO}_{3}\right]$, anhydrite $\left[\mathrm{CaSO}_{4}\right]$, and quartz. Similar phases were observed in longitudinal fractures found in the anhydrite zone.

The presence of $\mathrm{Mg}$-bearing accessory minerals was confirmed in the anhydrite host-rock images from secondary-emission and backscattered-emission scanning electron microscopy (SEM) of a polished surface of anhydrite show that the $\mathrm{Mg}$ was present in discrete areas, appearing as dark patches in Figure 7. Ion mapping of the sample indicated that the elements $\mathrm{Ca}$ and $\mathrm{S}$ were present together (i.e, $\mathrm{CaSO}_{4}$ ) in the lighter-colored areas, where $\mathrm{Mg}$ was absent. The presence of carbon associated with $\mathrm{Mg}$, as determined by energy-dispersive $\mathrm{x}$-ray fluorescence, suggests that $\mathrm{MgCO}_{3}$ is present, possibly with $\mathrm{MgO}$ or $\mathrm{Mg}(\mathrm{OH})_{2}$ or both.

The $\mathrm{Mg}$-rich areas in the anhydrite cannot be related to $\mathrm{Mg}$ in the grout, because the $\mathrm{Mg}$ content of the grout (1.5\% by mass) is lower than that of the bulk anhydrite samples ( 2 to $3 \%$ by mass). Bulk analyses also show that there is an increased level of $\mathrm{Mg}$ in the rock near the interface compared to the $\mathrm{Mg}$ level elsewhere in the rock ( $<0.5 \%$ by mass). By interaction with an $\mathrm{Mg}$-rich drilling fluid or dust-control brine, the $\mathrm{Mg}$ level in the vicinity of the hole may have increased after the hole was drilled and before the grout or concrete was poured. There are other possible explanations, but none seems to involve the grout.

The presence of Mg-bearing magnesite and sulfate-bearing gypsum filling cracks in both the concrete and salt layers indicates that these ions are moving in both obviously wet and apparently dry rock zones. "Dry" and "wet" refer to the condition at drilling in 1991. The source could be local or introduced brine and may involve dissolution of pre-existing phases. Furthermore, the presence of brucite only in the pilot holes open in concrete indicated that this phase probably precipitated in situ only where a magnesium source (presumably brine) encountered the increased pH of direct contact with the concrete. There is no evidence of precipitation of any phases directly removed from the concrete and no evidence of the porous microstructure that results from partial dissolution of cement.

One sample studied by SEM revealed perfectly formed clusters of magnesium hydroxy-chloride hydrate $\left[\mathrm{Mg}_{2}(\mathrm{OH})_{3} \mathrm{Cl} \cdot 4 \mathrm{H}_{2} \mathrm{O}\right]$ at the interface of host salt and concrete. This phase was common in highly altered portions of the waste-shaft concrete (Wakeley et al., 1992), but its presence was not confirmed by XRD in the PTM samples, so if present it is rare. No Mg-bearing phases are present in 
any interval within the matrix of the concrete: they are present only on free surfaces such as cracks and pilot holes, where fluids were free to migrate and where the hydrated cement phases controlled the $\mathrm{pH}$. Although $\mathrm{Mg}$ is present in the system, it has not caused the plug materials to alter.

\section{Disturbed Versus Undisturbed Rock}

The phase assemblages in concretes recovered from both the disturbed and undisturbed rock zones were the same. Visual examination of the cores revealed large discontinuities spaced at 3- to 5-in. intervals in both the salt and concrete sample cores from the DRZ, usually in association with a discontinuity in the rock such as a clay seam. These discontinuities were mineral-filled fractures. They were observed most easily on intact cores after push-out tests (Figure 8) and on core segments that had been sawn in half longitudinally. As noted previously, fractures also were observed in the concrete in the undisturbed rock, although they were more widely spaced. Even with this obvious difference in fracture frequency and therefore differences in opportunity for interaction with brine, the microstructure and phase composition in these intervals are very similar.

\section{Strong Versus Weak Interface Bond}

In general, bonds between salt host rock and concrete appeared strong and intact upon visual examination. Examples of concrete-to-salt bonds show good delineation between the concrete and the salt and look as if the concrete is encased in plastic (Figure 9). Further evidence of the bond integrity between the salt and the concrete is shown in the sample cores after push-out tests were performed (Figure 10). In this case, the failure occurred in the salt, apparently because of the extensive and typical fracture network. In sections of core in the undisturbed halite zone, failure occurred in the concrete, and a visible ring of concrete remained bound to the halite host (Figure 11). These bonds are characteristically stronger than the halite host rock or the concrete and demonstrate the compatibility between these two materials.

Both concrete core segments recovered from MB 139 showed marked reaction rims in the host anhydrite and had formed a weaker bond with the concrete than was exhibited by the lower undisturbed salt (Figure 12). These reaction rims are darker colored and more porous than the host rock. Samples taken from the intersection of the reaction rims and fractures were analyzed by XRD, 


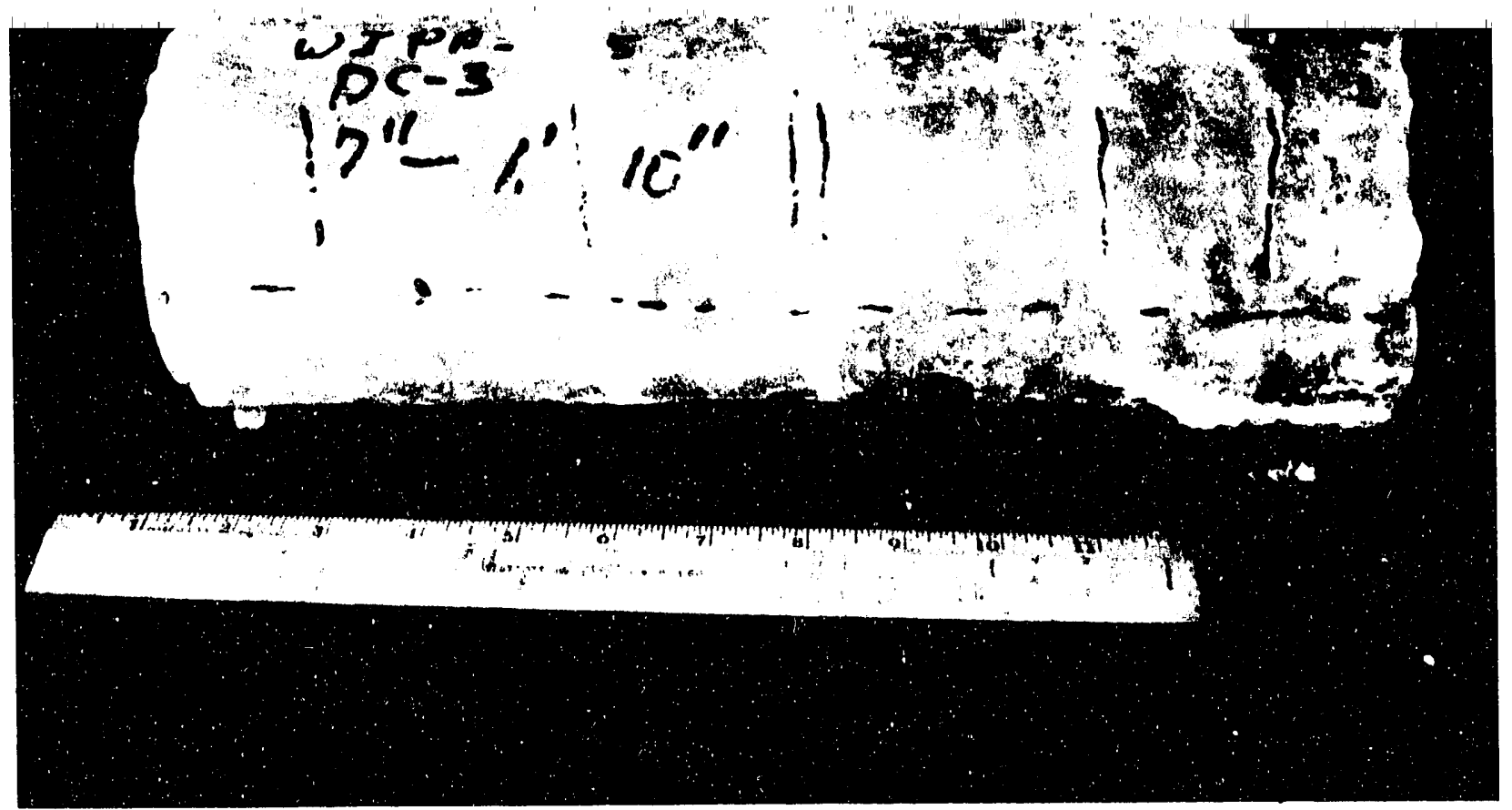

Figure 8. The concrete plug from the DRZ after push-out test, showing mineral-filled fractures. 


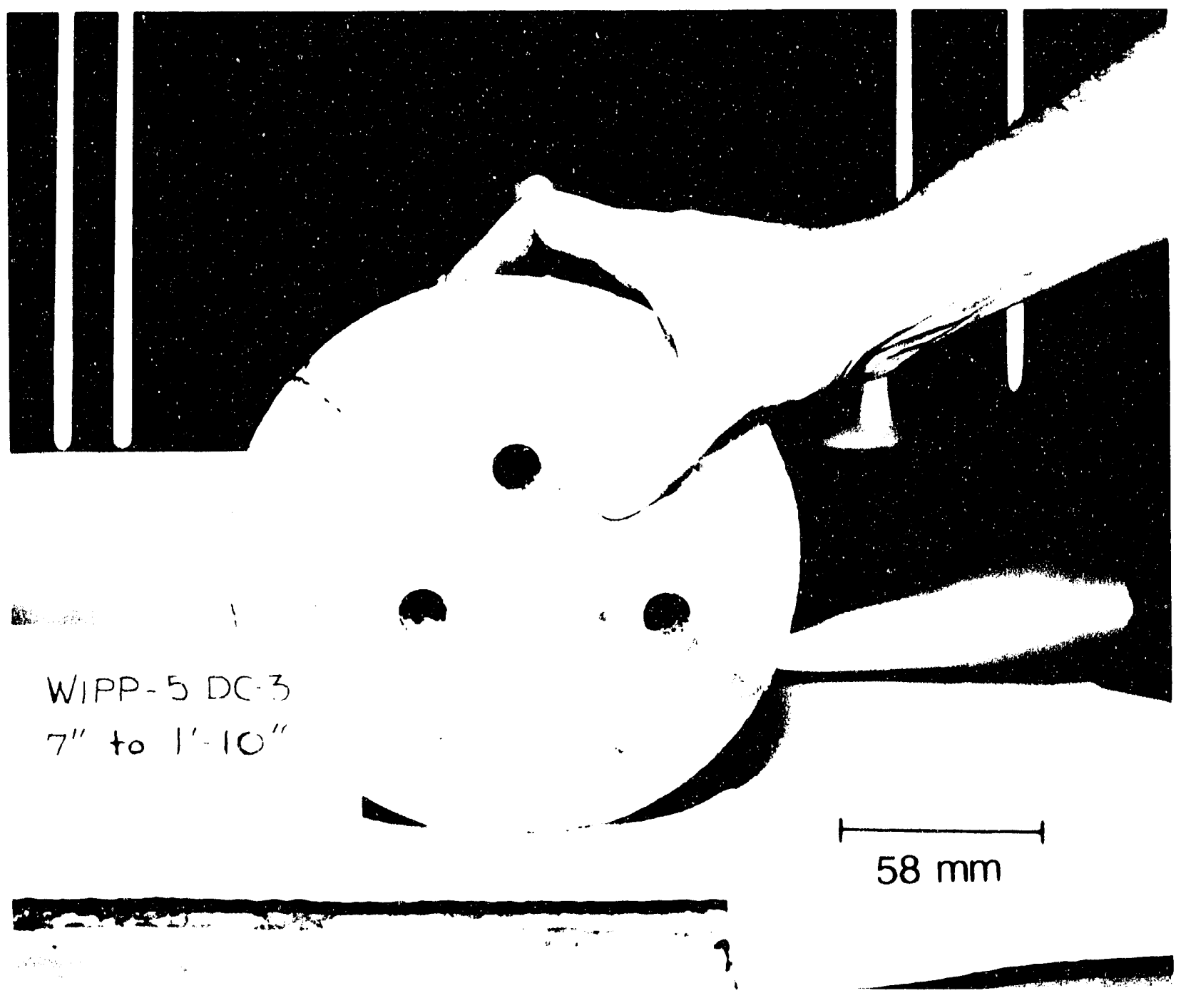

Figure 10. Concrete/halite core after push-out test, with breakthrough halite indicating strong bond between the salt and the concrete. 


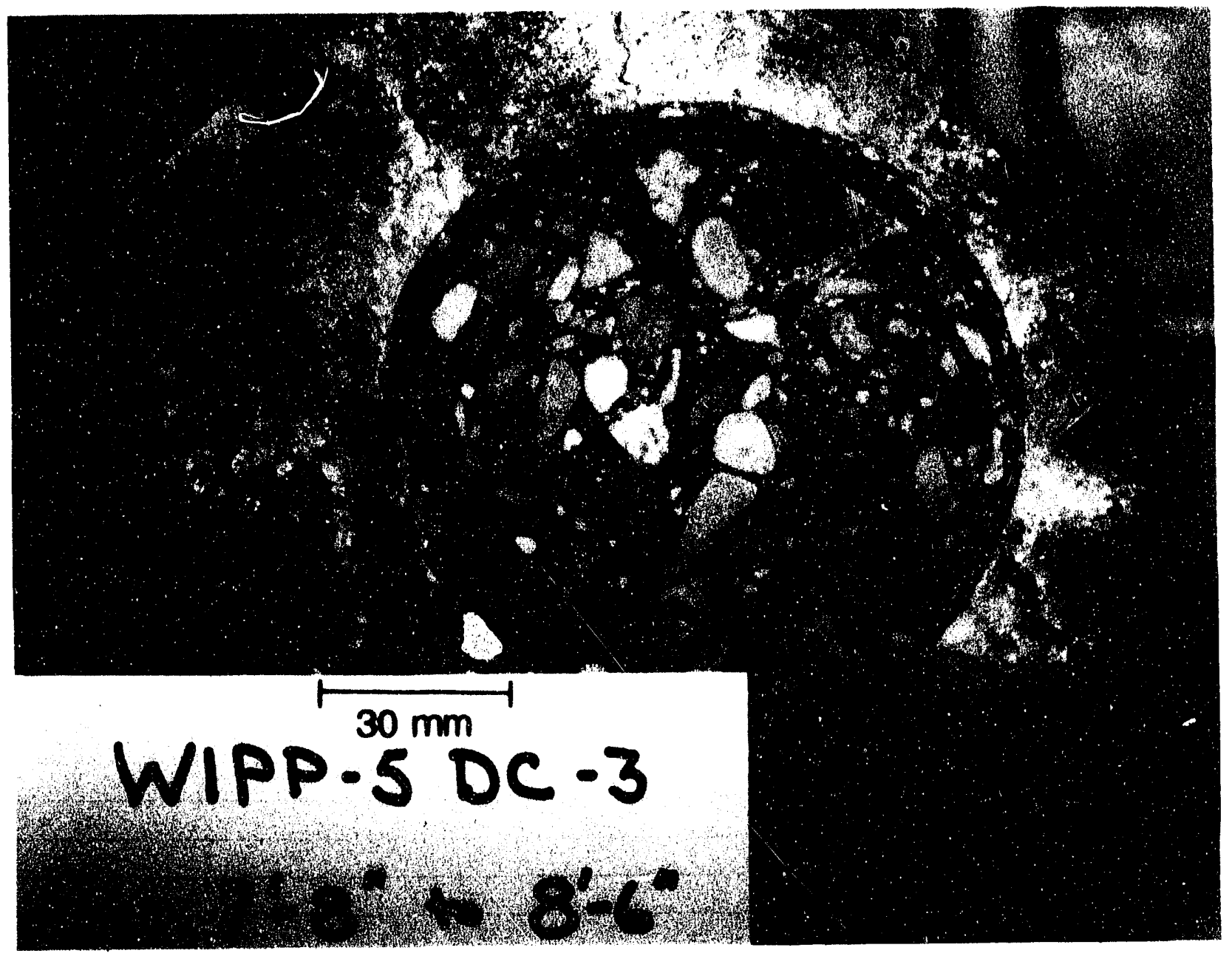

Figure 11. Concrete/halite core from the undisturbed halite zone where failure occurred in the concrete. 


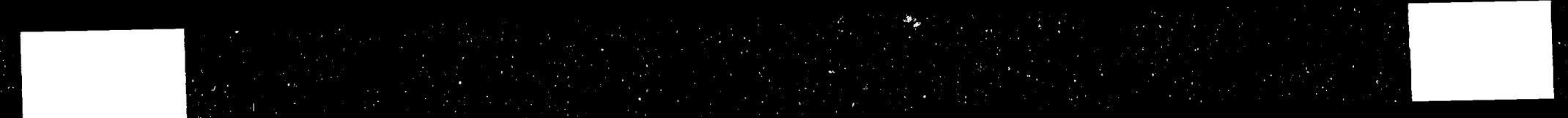


revealing halite, anhydrite, and quartz. Calcite, dolomite, gypsum, and magnesite were minor constituents. Halite was not detected in most reaction rim samples. This may indicate increased dissolution of the more soluble halite compared to the less soluble anhydrite. Further evidence for the poorer bond between the concrete and the anhydrite is shown in the sample cores after push-out tests were performed (Figure 13). In this example, the failure occurred at the interface of the concrete and the anhydrite host rock.

The grout formed a good bond with both the $\mathrm{NaCl}$ and $\mathrm{CaSO}_{4}$ host rock. A similar reaction ring was observed in the anhydrite host rock around both grout cores. The higher measured values for push-out strength of grout cores indicate that eccentricity of the plug in the overcore was more of a problem for the smaller-diameter cores. The very high value reported for push-out strength of grout in MB 139 (Figure 5) shows that the core was the most off-center, the diameter was small, and the anhydrite was stronger than halite. The push-out tests of grout from anhydrite measured the strength of the host rock, giving the highest values measured for this type of testing. The samples also failed along the bond when tested; that is, the rock and the bond failed, but the grout did not. 


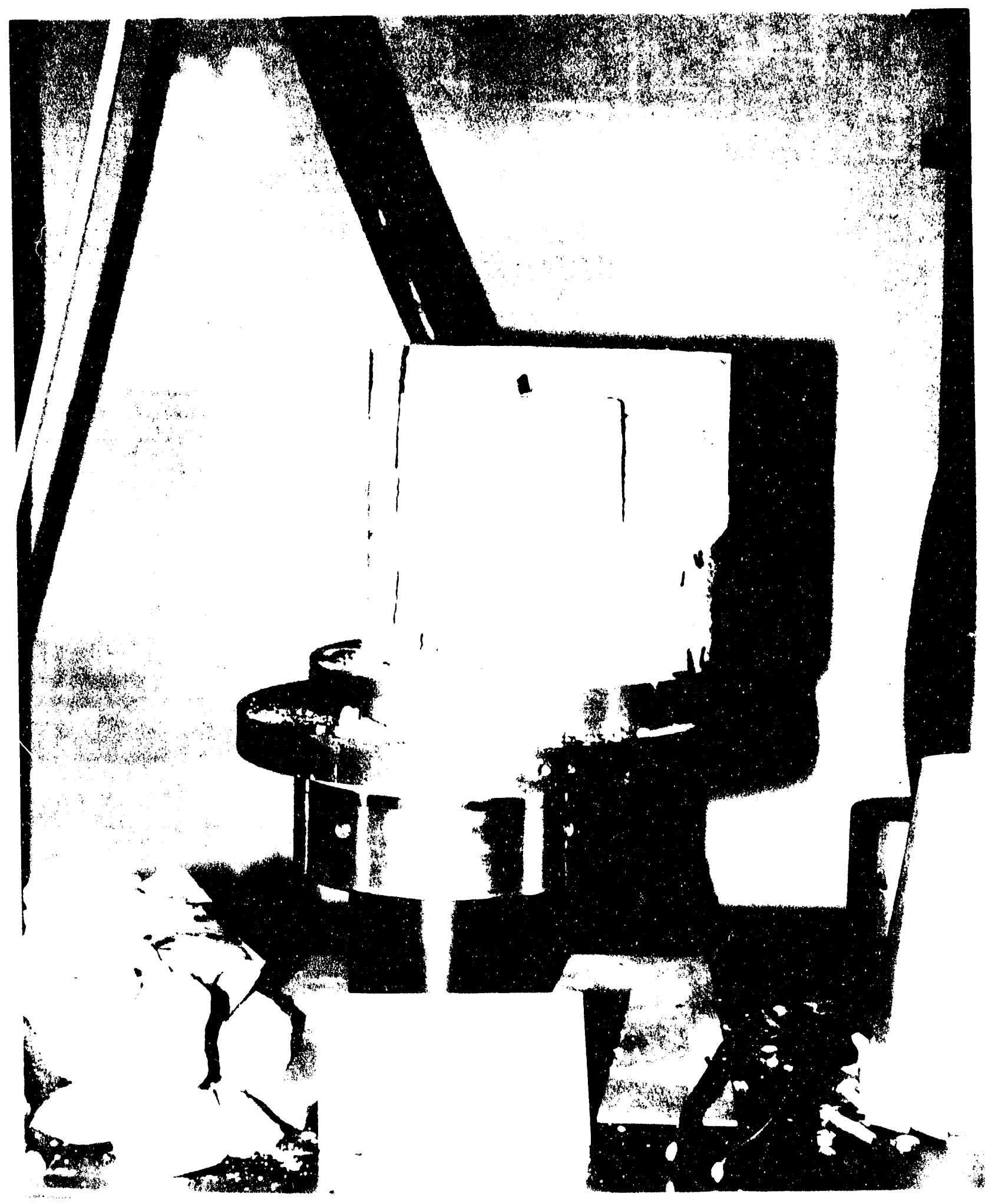




\section{DISCUSSION AND CONCLUSIONS}

All tests performed to assess material quality indicated that both the grout and the ESC performed very well. Values for compressive strength and pulse velocity of the grout equaled those measured within a few months after casting. Comparable values for the concrete exceeded previously reported values or exceeded reference values for good concrete. Both materials had visibly good bonds with the host salt rock, with measured bond strength increasing downward from the DRZ to the anhydrite into the undisturbed salt.

Measured push-out strengths for the grout were artificially high because of the eccentricity of samples. Direct observation of samples confirmed the eccentricity and confirmed that the anhydrite host rock had developed a porous reaction rim at the interface; the halite did not. This is consistent with previous studies of simulated borehole plugs in anhydrite in which porous reaction rims developed and prevented formation of a measurable bond (Moore et al., 1980; Gulick et al., 1980; Burkes and Rhoderick, 1983; Buck, 1985). The surprising feature of the present study is that the bond that formed between concrete or grout and anhydrite held the sample together through all cutting and handling.

There is evidence that indicates dissolution of $\mathrm{NaCl}$ in the anhydrite zone in the vicinity of the plugs, probably causing the increased porosity in anhydrite reaction rims. There also is evidence that the presence of halite promoted better bonding with the grout and concrete because the few areas that had mixed halite/anhydrite host rock were well bonded to the plugs in the halite-contact regions. There were no major differences in phase assemblage between samples recovered either wet or dry. All showed evidence of crystallization of new phases on free surfaces but no major changes in phase assemblage since the assemblage was originally documented. This was true even where the rock was highly fractured, which could have enhanced brine movement; and where pilot holes were present through the concrete, which could have had the same effect. In fact, the crystallization of new phases on these free surfaces indicates that strongly ionic Mg-bearing fluids were present and moving. But the stability of the phase assemblage in the cement-based materials indicates that they were essentially unaffected by this movement other than to improve bonding to host salt rock.

One of the questions asked about grout or concrete since the inception of geochemical studies in support of the SSSPT is: is the phase assemblage of this material inherently unstable in its service environment? This instability presumably would be indicated by major phase changes in a fairly short 
time, with concomitant deterioration in physical properties. It appears that these materials were stable in their service environment, and their physical properties were favored.

The ESC is in much better condition than the concrete taken from the waste shaft at the 834-ft construction joint (Nowak et al., 1993) after roughly the same length of time in service. The concrete in the PTM apparently was exposed to far less fluid and slower fluid transport. It probably also encountered far less magnesium, even though there are $\mathrm{Mg}$-bearing phases even on free surfaces. $\mathrm{Mg}$ phases are absent from the hydrated-cement phase assemblage. There is no doubt that in this particular WIPP sub-environment, both the grout and the WES concrete performed well and that long-term chemical stability is indicated as long as service conditions remain constant. That is, where $\mathrm{Mg}$ level and fluid availability are low and there is no potential gradient to force the fluids through the concrete, a concrete formulated carefully for this environment should be durable. We cannot judge the relative resistance to $\mathrm{Mg}$-related deterioration or the waste-shaft concrete versus the ESC because they were in such apparently different service conditions. The differences in their appearances, strength, and phase assemblages is striking.

The Mg-bearing phases had not been identified in previous studies of the grout or concrete, from samples cast in the field and stored in air or from small samples recovered in 1985 from the PTM. The fact that $\mathrm{Mg}$ phases are present in the 1991 recovered samples, even though they only fill fractures and cling to free surfaces and possibly interfaces, means that $\mathrm{Mg}$ was available from some source in this environment and it was mobile. Previous and current studies at the WES and other field experiences show the potential for concrete to deteriorate in high-Mg brines. Despite the obvious availability of $\mathrm{Mg}$, a transport medium, and access of these to the concrete, the concrete and grout were stronger than they were six years previously, and their phase assemblages apparently were stable.

In all conditions and for both materials, the lowest measured values for a particular property were from grout or concrete recovered from the DRZ. The DRZ will present the greatest challenges to material performance and will need special grouting or other treatment to achieve performance compatible with other rock zones in the repository. 


\section{REFERENCES}

Akgun, H., and J.J.K. Daemen. 1991. Bond Strength of Cementitious Borehole Plugs in Welded Tuff. NUREG/CR-4295. Washington, DC: US Nuclear Regulatory Commission, Office of Nuclear Regulatory Research, Division of Engineering.

American Society for Testing and Materials (ASTM). 1991. 1991 Annual Book of ASTM Standards. Section 4, Vol. 04.01 and 04.02. Philadelphia, PA: American Society for Testing and Materials.

Borns, D.J. 1985. Marker Bed 139: A Study of Drillcore from a Systematic Array. SAND85-0023. Albuquerque, NM: Sandia National Laboratories.

Borns, D.J. and J.C. Stormont. 1989. "An Interim Report on Excavation Effect Studies at the Waste Isolation Pilot Plant: The Delineation of the Disturbed Rock Zone," Proceedings of an NEA Workshop on Excavation Response in Geological Repositories for Radioactive Waste, Winnipeg, Canada, April 26-28, 1988. SAND87-1375. Paris, France: Organisation for Economic CoOperation and Development. 413-425.

Buck, A.D. 1985. Development of a Sanded Nonsalt Expansive Grout for Repository Sealing Application. Miscellaneous Paper SL-85-6. Vicksburg, MS: Department of the Army, Waterways Experiment Stations, Corps of Engineers.

Burkes, J.P., and J.E. Rhoderick. 1983. Petrographic Examination of Bell Canyon Tests (BCT) 1FF Field Grouts Over a Three-Year Period. Miscellaneous Paper SL-83-12; SAND83-7115. Vicksburg, MS: US Army Engineer Waterways Experiment Station.

Comes, G.D., L.D. Wakeley, and E.F. O'Neill, III. 1987. Properties of Laboratory-Tested Specimens of Concrete from Small-Scale Seal P'erformance Tests at the Waste Isolation Pilot Plant. Miscellaneous Paper SL-87-9. Vicksburg, MS: US Army Engineer Waterways Experiment Station.

Gulick, C.W. 1984. "Test Plan, Plug Test Matrix." Albuquerque, NM: Sandia National Laboratories. (Copy on file at the Waste Management and Transportation Library, Sandia National Laboratories, Albuquerque, NM).

Gulick, C.W., [Jr.], and L.D. Wakeley. 1989. Reference Properties of Cement-Based Plugging and Sealing Materials for the Waste Isolation Pilot Plant (WIPP). Technical Report SL-89-17. Vicksburg, MS: US Army Engineer Waterways Experiment Station.

Gulick, C.W., Jr., J.A. Boa, Jr. and A.D. Buck. 1980. Bell Canyon Test (BCT) Cement Grout Development Report. SAND80-1928. Albuquerque, NM: Sandia National Laboratories.

Lambert, S.J., E.J. Nowak, L.D. Wakeley, and T.S. Poole. 1992. Interactions Between Concrete and Brine at the Waste Isolation Pilot Plant (WIPP) Site, New Mexico. SAND91-1421. Albuquerque, NM: Sandia National Laboratories. 
Malhotra, V.M. 1976. "Chapter 5: Dynamic or Vibration Methods: Theoretical Basis of Dynamic Methods," Testing Hardened Concrete: Nondestructive Methods. ACI Monograph No. 9. Ames, IA: The Iowa State University Press; Detroit, MI: American Concrete Institute. 52-102.

Moore, J.G., M.T. Morgan, E.W. McDaniel, H.B. Greene, and G.A. West. 1980 . Cement Technology for Plugging Boreholes in Radioactive Was 'Repository Sites: Progress Report for the Period October 1, 1978, to September 30, 1979. ORNL-5610. Oak Ridge, TN: Oak Ridge National Laboratory.

Nowak, E.J., L.D. Wakeley, T.S. Poole, and J.P Burkes. 1993. Investigations of Deteriorated Concrete from the Liner of the Waste Isolation Pilot Plant Waste Shaft. SAND91-2733. Albuquerque, NM: Sandia National Laboratories.

Roy, D.M., M.W. Grutzeck, ana L.D. Wakeley. 1985. Salt Repository Seal Materials: A Synopsis of Early Cementitious Materials Development. BMI/ONWI-536. Columbus, OH: Office of Nuclear Waste Isolation, Battelle Memorial Institute.

Stormont, J.C. 1984. Plugging and Sealing Program for the Waste Isolation Pilot Plant (WIPP). SAND84-1057. Albuquerque, NM: Sandia National Laboratories.

Stormont, J.C., ed. 1986. Development and Implementation: Test Series A of the Small-Scale Seal Performance Tests. SAND85-2602. Albuquerque, NM: Sandia National Laboratories.

Wakeley, L.D. 1987. Dependence of Expansion of a Salt-Saturcted Concrete on Temperature and Mixing and Handling Procedures. Technical Report SL-87-20. Vicksburg, MS: US Army Engineer Waterways Experiment Station.

Wakeley, L.D., and T.S. Poole. 1986. Posttest A. alysis of a Laboratory-Cast Monolith of SaltSaturated Concrete. Miscellaneous Paper SL-8u-13. Vicksburg, MS: US Army Engineer Waterways Experiment Station.

Wakeley, L.D., and T.S. Poole. 1987. Studies of the Geochemical Stability of a Salt- iaturated Expansive Grout. Miscellaneous Paper SL-87-10. Vicksburg, MS: US Army Naterways Experiment Station.

Wakeley, L.D., and D.M. Walley. 1986. Development and Field Placement of an Expansive SaltSaturated Concrete (ESC) for the Waste isnlation Pilot Plant (WI D). Technical Report SL-86-36. Vicksburg, MS: US Army Engineer Waterways Experirnent Station.

Wakeley, L.D., T.S. Poole, and J.P. Burkes. 1992. Deteriorated Concrete from Liner of WIPP Waste Shaft. Technical Report SL-92-14. Vicksburg, MS: Army Engineer Waterways Experiment Station. 
APPENDIX A: MIXTURE PROPORTIONS FOR GROUT AND CONCRETE AND GROUT PROPERTIES MEASURED DURING PREVIOUS RESEARCH 
*.

A-2 
Table A-1. Components and Proportions of Salt-Saturated Grout (BCT-1F) (from Gulick and Wakeley, 1989)

\begin{tabular}{|c|c|c|c|}
\hline Component & $\begin{array}{l}\% \text { of Total } \\
\text { by Mass }\end{array}$ & $\begin{array}{c}\text { \% of Total Solids by } \\
\text { Mass }\end{array}$ & $\begin{array}{c}\text { Batch Weight for } 1 \mathrm{t}^{3}, \\
\mathrm{lb}\end{array}$ \\
\hline Class H Cement & 48.3 & 61.2 & 61.9 \\
\hline Class C Fly Ash & 16.2 & 20.6 & 20.8 \\
\hline Cal Seal (Plaster) & 5.7 & 7.2 & 7.3 \\
\hline Salt $(\mathrm{NaCl})$ & 7.9 & 10.0 & 10.1 \\
\hline Dispersant & 0.78 & 1.0 & 1.0 \\
\hline Defoamer & 0.02 & 0.02 & 0.02 \\
\hline \multirow[t]{2}{*}{ Water } & 21.1 & - & 27.1 \\
\hline & 100.0 & 100.02 & 128.22 \\
\hline
\end{tabular}


Table A-2. Components and Proportions of Expansive Salt-Saturated Concrete (ESC) (from Wakeley, 1987)

\begin{tabular}{|c|c|c|c|}
\hline Component & $\begin{array}{l}\% \text { of Total } \\
\text { by Mass }\end{array}$ & $\begin{array}{c}\text { \% of Total Solids by } \\
\text { Mass }\end{array}$ & $\begin{array}{c}\text { Batch Weight for } \\
1 \mathrm{yd}^{3} \cdot 1 \mathrm{~b} \\
\end{array}$ \\
\hline Class H Cement & 9.03 & 9.66 & 365 \\
\hline Chem Comp III & 6.02 & 6.45 & 243 \\
\hline Cal-Seal & 1.80 & 1.94 & 73 \\
\hline Class C Fly Ash & 5.10 & 5.44 & 205 \\
\hline Fine Aggregate & 34.11 & 36.50 & 1,365 \\
\hline Coarse Aggregate & 34.58 & 37.00 & 1,381 \\
\hline $\mathrm{NaCl}$ & 2.50 & 2.65 & 100 \\
\hline Defoaming Agent & 0.21 & 0.24 & 9 \\
\hline Na Citrate & 0.11 & 0.12 & 4.4 \\
\hline \multirow[t]{2}{*}{ Water (Iced) } & 6.60 & - & 292 \\
\hline & 100.06 & 100.00 & $4,037.4$ \\
\hline
\end{tabular}


Table A-3. PTM (BCT-1F) Specimens Tested in 1987

\begin{tabular}{|c|c|c|c|c|}
\hline $\begin{array}{c}\text { Specimen } \\
\text { Size } \\
\text { (inches) }\end{array}$ & $\begin{array}{l}\text { Type } \\
\text { Mold }\end{array}$ & $\begin{array}{l}\text { Condition after } \\
\text { Stripping }\end{array}$ & $\begin{array}{l}\text { Pulse Velocity } \\
\text { (ft/sec) }\end{array}$ & $\begin{array}{r}\text { Compressive } \\
\text { Strength (psi) }\end{array}$ \\
\hline $3 \times 6$ & Steel & Cracked & $\begin{array}{r}12,280 \\
9,640 \\
10,962 \\
9,640 \\
11,259\end{array}$ & $\begin{array}{l}4,910 \\
2,220 \\
3,890 \\
3,620 \\
4,130\end{array}$ \\
\hline $4 \times 8$ & Plastic & & $\begin{array}{l}11,726 \\
11,549 \\
12,121 \\
12,287 \\
12,333 \\
12,191 \\
11,607\end{array}$ & $\begin{array}{l}\mathbf{5}, 170 \\
3,580 \\
7,250 \\
6,630 \\
5,490 \\
4,610 \\
3,580\end{array}$ \\
\hline $6 \times 12$ & Plastic & & $\begin{array}{l}11,666 \\
12,229 \\
12,229 \\
11,991 \\
11,646\end{array}$ & $\begin{array}{l}5,310 \\
6,540 \\
6,970 \\
2,190 \\
2,920\end{array}$ \\
\hline $6 \times 12$ & Steel & & $\begin{array}{l}11,173 \\
11,048 \\
12,339 \\
12,229\end{array}$ & $\begin{array}{l}3,360 \\
4,230 \\
5,010 \\
4,160\end{array}$ \\
\hline
\end{tabular}


Table A-4. PTM (BCT-1F) Specimens Tested in 1984 Cast in Steel Molds

\begin{tabular}{|c|c|c|c|}
\hline $\begin{array}{l}\text { Specimen } \\
\text { Size } \\
\text { (inches) }\end{array}$ & $\begin{array}{l}\text { Age } \\
\text { Days }\end{array}$ & $\begin{array}{l}\text { Compressive } \\
\text { Strength (psi) }\end{array}$ & $\begin{array}{l}\text { Pulse Velocity } \\
\text { (ft/sec) }\end{array}$ \\
\hline $2 \times 2 \times 2$ & 30 & $\begin{array}{l}5,330 \\
5,830 \\
3,520 \\
4,810\end{array}$ & \\
\hline $2 \times 2 \times 2$ & 68 & $\begin{array}{l}5,875 \\
6,500 \\
4,820 \\
5,480\end{array}$ & \\
\hline $3 \times 6$ & 103 & $\begin{array}{l}8,810 \\
8,240\end{array}$ & \\
\hline $1 \times 1 \times 12$ & 30 & & $\begin{array}{l}9,417 \\
9,417 \\
9,232 \\
9,061 \\
9,014 \\
9,282 \\
9,191 \\
8,844 \\
8,968 \\
9,014 \\
8,928\end{array}$ \\
\hline $2 \times 2 \times 12$ & 30 & & $\begin{array}{r}8,849 \\
9,592 \\
9,566 \\
10,190 \\
9,135\end{array}$ \\
\hline $3 \times 3 \times 12$ & 30 & & $\begin{array}{l}8,987 \\
9,232 \\
9,150 \\
9,083\end{array}$ \\
\hline
\end{tabular}


APPENDIX B: DATA FROM TESTS OF PHYSICAL PROPERTIES 1991

B-1 
B-2 
Table B-1. Data from Static Pulse Velocity Measurements on BCT-1F Grout Samples Removed from the PTM, 1991

\begin{tabular}{|c|c|c|}
\hline Sample & $\begin{array}{c}\text { Pulse Velocity } \\
\text { Measurement }(\mathrm{ft} / \mathrm{sec})\end{array}$ & Host Rock \\
\hline L1SO1 - No. 6 & & Undisturbed Halite \\
\hline 8.17 to $9.08 \mathrm{ft}$. & 10,205 & \\
\hline 9.17 to $9.83 \mathrm{ft}$. & 9,012 & \\
\hline 9.83 to $10.58 \mathrm{ft}$. & 10,417 & \\
\hline L1SO2 - Ne. 1 & & Disturbed Halite \\
\hline 0.00 to $0.33 \mathrm{ft}$. & 4,412 & \\
\hline 1.00 to $1.25 \mathrm{ft}$. & 3,788 & \\
\hline 1.58 to $1.83 \mathrm{ft}$. & 5,859 & \\
\hline$\underline{\mathrm{L}} \mathrm{SO} 02-\mathrm{No} .3$ & & Anhydrite Bed \\
\hline 5.42 to $5.67 \mathrm{ft}$. & 9,167 & \\
\hline 6.67 to $7.17 \mathrm{ft}$. & 3,580 & \\
\hline
\end{tabular}

Table B-2. Data from Compression Strength Testing on BCT-1F Grout Samples Removed from the PTM, 1991

\begin{tabular}{|c|c|c|}
\hline Sample & $\begin{array}{l}\text { Compressive Strength } \\
\left(\mathrm{lbs} / \mathrm{in}^{2}\right)\end{array}$ & Host Rock \\
\hline L1S01 - No. 6 & & \\
\hline 9.17 to $9.83 \mathrm{ft}$. & 8,820 & Undisturbed Halite \\
\hline$\underline{\mathrm{L}} \mathrm{SO} \mathrm{L}_{2}-\mathrm{No} \cdot 1$ & & \\
\hline 1.00 to $1.25 \mathrm{ft}$ & 5,490 & Disturbed Halite \\
\hline$\frac{\mathrm{L} 1 \mathrm{SO2}-\mathrm{No} .3}{5.42 \text { to } 5.67 \mathrm{ft} \text {. }}$ & 8,400 & Anhydrite \\
\hline
\end{tabular}


Table B-3. Data from Push-Out Testing on BCT-1F Grout Samples Removed from the PTM, 1991

\begin{tabular}{|c|c|c|}
\hline Sample & $\begin{array}{l}\text { Push-Out Strength } \\
\text { (lbs/in }{ }^{2} \text { Shear) }\end{array}$ & Host Rock \\
\hline \multicolumn{3}{|l|}{ L1SO1 - No. 6} \\
\hline 8.17 to $9.08 \mathrm{ft}$. & 488 & Undisturbed Halite \\
\hline 9.83 to $10.58 \mathrm{ft}$. & 533 & Undisturbed Halite \\
\hline \multicolumn{3}{|l|}{$\mathrm{L} 1 \mathrm{SO} 2$ - No. 1} \\
\hline 0.00 to $0.33 \mathrm{ft}$. & 149 & Disturbed Halite \\
\hline 1.58 to $1.83 \mathrm{ft}$. & 409 & Disturbed Halite \\
\hline \multicolumn{3}{|l|}{$\underline{\mathrm{L}} \mathrm{SO} \mathrm{O} 2-\mathrm{No}, 3$} \\
\hline 6.67 to $7.17 \mathrm{ft}$. & 576 & Anhydrite \\
\hline
\end{tabular}

Table B-4. Data from Static Pulse Velocity Measurements on ESC Samples Removed from the PTM, 1991

\begin{tabular}{|c|c|c|}
\hline Sample & $\begin{array}{c}\text { Pulse Velocity } \\
\text { Measurement (ft/sec) }\end{array}$ & Host Rock \\
\hline$\frac{\mathrm{L} 1 \mathrm{~S} 13-\mathrm{No} .1}{0.58 \text { to } 1.83 \mathrm{ft}}$ & 7,803 & Disturbed Halite \\
\hline 1.83 to $2.88 \mathrm{ft}$. & 14,244 & Disturbed Halite \\
\hline$\frac{\text { L1S13 }- \text { No. } 3}{6.38 \text { to } 7.50 \mathrm{ft}}$ & 14,661 & Anhydrite Bed \\
\hline$\frac{\mathrm{L} 1 \mathrm{~S} 13-\mathrm{No} .4}{7.67 \text { to } 8.50 \mathrm{ft}}$ & 15,424 & Undisturbed Halite \\
\hline 8.58 to $9.92 \mathrm{ft}$. & 15,278 & Undisturbed Halite \\
\hline$\frac{\mathrm{L} 1 \mathrm{~S} 14-\mathrm{No} .2}{2.25 \text { to } 2.88 \mathrm{ft}}$ & 15,000 & Disturbed Halite \\
\hline 2.88 to $3.50 \mathrm{ft}$. & 14,571 & Disturbed Halite \\
\hline$\frac{\mathrm{L} 1 \mathrm{~S} 14-\mathrm{No} .4}{6.50 \text { to } 7.42 \mathrm{ft}}$ & 15,458 & Anhydrite Bed \\
\hline$\frac{\text { LIS14 }-\mathrm{No} .5}{7.83 \text { to } 9.00 \mathrm{ft} \text {. }}$ & 14,524 & Undisturbed Halite \\
\hline
\end{tabular}


Table B-5. Data from Compressive Strength Testing on ESC Samples Removed from the PTM, 1991

\begin{tabular}{|c|c|c|}
\hline Sample & $\begin{array}{l}\text { Compressive Strength } \\
\left.\text { (lbs/in }{ }^{2}\right)\end{array}$ & Host Rock \\
\hline$\frac{\mathrm{LIS13}-\mathrm{No} .1}{1.83 \text { to } 2.88 \mathrm{ft}}$ & $\begin{array}{l}9,710 \\
8,180\end{array}$ & Disturbed Halite \\
\hline$\frac{\mathrm{L}, \mathrm{SS} 13-\mathrm{No} .3}{6.38 \text { to } 7.50 \mathrm{ft} .}$ & $\begin{array}{r}11,340 \\
8,990\end{array}$ & Anhydrite \\
\hline$\frac{\mathrm{L} 1 \mathrm{~S} 13-\mathrm{No} .4}{8.58 \text { to } 9.92 \mathrm{ft}}$ & $\begin{array}{r}8,000 \\
10,640 \\
10,820\end{array}$ & Undisturbed Halite \\
\hline
\end{tabular}

Table B-6. Data from Push-Out Testing on ESC Samples Removed from the PTM, 1991

\begin{tabular}{|c|c|c|}
\hline Sample & $\begin{array}{l}\text { Push-Out Strength } \\
\text { (lbs/in }{ }^{2} \text { Shear) }\end{array}$ & Host Rock \\
\hline$\frac{\mathrm{L} 1 \mathrm{~S} 13-\mathrm{No}, 1}{0.58 \text { to } 1.83 \mathrm{ft}}$ & 197 & Disturbed Halite \\
\hline$\frac{\mathrm{L} 1 \mathrm{~S} 13-\mathrm{No}, 4}{7.67 \text { to } 8.50 \mathrm{ft}}$ & 338 & Undisturbed Halite \\
\hline$\frac{\mathrm{L} 1 \mathrm{~S} 14-\mathrm{No} .2}{2.25 \text { to } 2.88 \mathrm{ft} .}$ & 117 & Disturbed Halite \\
\hline$\frac{\mathrm{L} 1 \mathrm{~S} 14-\mathrm{No} .4}{6.50 \text { to } 7.42 \mathrm{ft}}$ & 267 & Anhydrite Bed \\
\hline
\end{tabular}




\section{APPENDIX C: PUSH-OUT RESISTANCE TEST METHOD}




\section{C-2}


Scope. The push-out resistance test was devised to measure the force or pressure required to displace concrete or grout plugs cast in a rock medium. Measured values and visual inspection of fracture surfaces represent the quality of cement-based materials at the interface with the rock medium.

Significance and Use. Test methodology is similar to a modified shear bond test used to determine the bond and shear resistance between two concrete specimens produced by an epoxy binder. This push-out test can be performed on different shape specimens as long as the bonded surface of the plug remains parallel to the direction of applied force. Deviations of bonded surfaces from parallel would produce additional stresses not normally associated with bond-type tests. Conical or undulating surfaces increase the measured bond strength.

Apparatus. The test machine is a closed-loop hydraulically-actuated MTS materials testing machine. Load-controlled-type controllers applied a constant force or pressure to the plug instead of a displacement-type (screw-type) which applies a constant movement of compression platens with variable force. The interface between the concrete or grout and host rock is required to resist plug movemei: from the rock under constant pressure rather than constant movement.

The lowei platen was a machined 1.0-in. thick hardened-steel compressive ring. Hardened-steel rings serve as reaction platens for the test specimen with the center portion removed to accommodate plug material movement. The inside diameter of the ring removed portion is machined to the plug diameter plus 0.25 -in. allouing only the plug to be pushed out of the specimen. The outside diameter of the ring is $\mathrm{m}^{-}$:hined to 2.0 -in. plus the diameter of the test specimen.

Retaining sleeves were molded 0.0625-in. thick sheet metal cylindrical molds with clamping lips. Retaining sleeves serve to confine stresses allowing generated lateral stresses from vertical loading to dissipáce. Allowing lateral stresses to dissipate into the mold prevents reaction against possibly weaker and brittle rock or the salt zone surrounding the specimen. Actual field plugs are surrounded or confined with the host rock or salt medium and the lateral forces acting upon plugs would distribute through the surrounding medium.

The upper platen was a machined piston used to push the plug out of the rock medium. The piston was the same diametrical dimension or slightly less than that of the plug. The piston lengths were required to be greater than 1 -in. to accommodate the full breakage of the bond at the interface.

Test Specimens. Concrete and grout plugs were over-cored from the field site to include the host rock surrounding the plugs. The recovered cores removed from the site were extracted with coring devices having an inside diameter of twice the plug diameter (i.e. 2-in. diam. plugs were cored with a 4-in. diam. coring head). The test specimens were maintained in their as-received condition throughout the tesiing except during preparation for pesh-out testing.

Specimens selected for push-out testing were then sawer or ground smooth on each end. Sawing or grinding of ends were to within 0.001-in. planener, and normal to the plug to within \pm 20 . Recovered core heights were maintained as much as possible. Final heights and diameters of both the plugs and host rock cores were recorded to the nearest 0.01 -in. 
Procedure. Place the test specinien on the ring platen. Center the plug in-line with the inside diameter of the ring. Slide the retaining sleeve over the test specimen and clamp in place. Caution must be observed to prevent movement of the specimen off alignment with the ring platen. Tighten the sleeve until it becomes snug around the specimen.

Center the test specimen with the upper platen of the test machine. Place the matching diameter piston directly in-line with the plug. Lower the upper platen to a contact position with the piston. Adjust the alignment as necessary between the ring platen, plug, piston, and upper platen.

Test the specimen in a load-controlled mode at the rate of 20 to $40 \mathrm{psi} / \mathrm{sec}$ based upon the diameter of the plug and not the entire core.

Calculations. The relative bond strength between the plug and host rock $\left(S_{b}\right)$ is equal to the load $\left(\mathrm{P}_{f}\right)$ required to dislodge the plug from the host material divided by the contact area of the bond $\left(A_{c}\right)$. The bond contact area is lateral surface area of the plug in contact with the host rock. For example:

$$
A_{c}=2 \pi r l
$$

$r$ = mean radius of the plug as measured at the top and bottom of the plug

1 = length of the plug as measured from the top to bottom

$$
S_{b}=P_{f} \div A_{c}
$$

$S_{b}=$ calculated bond strength at the plug interface

$P_{\mathrm{f}}=$ observed maximum load to displace the plug from its host rock Results are reported to the nearest $10 \mathrm{lb} / \mathrm{in}^{2}$. 


\section{DISTRIBUTION}

\section{Federal Agencies}

US Department of Energy (5) Office of Civilian Radioactive Waste Management

Attn: Deputy Director, RW-2

Associate Director, RW-10 Office of Program Administration and Resources Management

Associate Director, RW-20 office of Facilities Siting and Development Associate Director, RW- 30 Office of Systems Integration and Regulations

Associate Director, RW-40 Office of External

Forrestal Building Relations and Policy

Washington, DC 20585

US Department of Energy (4)

WIPP Project Integration office

Attn: W.J. Arthur III

L.W. Gage

P.J. Higgins

D.A. Olona

PO Box 5400

Albuquerque, NM 87115-5400

US Department of Energy

Attn: National Atomic Museum Library Albuquerque Operations Office PO Box 5400

Albuquerque, NM 87185-5400

US Department of Energy (4) WIPP Project Site Office (Carlsbad)

Attn: R. Becker

V. Daub

J. Lippis J.A. Mewhinney

PO Box 3090

Car1sbad, NM 88221

US Department of Energy

Research \& Waste Management Division Attn: Director

PO Box E

Oak Ridge, TN 37831
US Department of Energy

Attn: E. Young

Room E-178

GAO/RCED/GTN

Washington, DC 20545

US Department of Energy

Office of Environmental Restoration and Waste Management

Attn: J. Lytle, EM-30 (Trevion II)

Washington, DC 20585-0002

US Department of Energy (3)

Office of Environmental Restoration and Waste Management

Attn: M. Frei, EM-34 (Trevion II)

Washington, DC 20585-0002

US Department of Energy

Office of Environmental Restoration and Waste Management

Attn: S. Schneider, EM-342

(Trevion II)

Washington, DC 20585-0002

US Department of Energy (3)

office of Envixonment, Safety and Health

Attn: C. Borgstrom, EH-25

R. Pelletier, EH-231

Washington, DC 20585

US Department of Energy (2)

Idaho Operations office

Fuel Processing and Waste

Management Division

785 DOE Place

Idaho Falls, ID 83402

US Environmental Protection Agency (2)

Radiation Programs (ANR-460)

Attn: M. Oge

Washington, DC 20460

US Geological Survey (2)

Water Resources Division

Attn: R. Livingston

4501 Indian School NE

Suite 200

Albuquerque, NM 87110 
US Nuclear Regulatory Commission Attn: H. Marson

Mail Stop 623SS

Washington, DC 20555

\section{Boards}

Defense Nuclear Facilities Safety Board

Attn: D. Winters

625 Indiana Ave. NW, Suite 700

Washington, DC 20004

Nuclear Waste Technical Review Board (2)

Attn: Chairman

$$
\text { S.J.S. Parry }
$$

1100 Wilson Blvd., Suite 910

Arlington, VA 22209-2297

Advisory Committee on Nuclear

Waste

Nuclear Regulatory Commission

Attn: R. Major

7920 Norfolk Ave.

Bethesda, MD 20814

\section{State Agencies}

Environmental Evaluation Group (3)

Attn: Library

7007 Wyoming NE

Suite F-2

Albuquerque, NM 87109

NM Bureau of Mines and Mineral

Resources

Socorro, NM 87801

NM Energy, Minerals, and Natural Resources Department

Attn: Library

2040 S. Pacheco

Santa Fe, NM 87505

NM Environment Department (3)

Secretary of the Environment

Attn: J. Espinosa

1190 St. Francis Drive

Santa Fe, NM 87503-0968

NM Environment Department

WIPP Project Site

Attn: P. McCasland

PO Box 3090

Carlsbad, NM 88221

\section{Laboratories/Corporations}

Battelle Pacific Northwest

Laboratories

Attn: R.E. Westerman, MSIN P8-44

Battelle Blvd.

Richland, WA 99352

INTERA Inc.

Attn: J.F. Pickens

6850 Austin Center Blvd.

Suite 300

Austin, TX 78731

INTERA Inc.

Attn: W. Stensrud

PO Box 2123

Carlsbad, NM 88221

IT Corporation

Attn: R.F. McKinney

Regional office

5301 Central NE, Suite 700

Albuquerque, NM 87108

Los Alamos National Laboratory

Attn: B. Erda1, CNC-11

PO Box 1663

Los Alamos, NM 87544

$\mathrm{RE} / \mathrm{SPEC}$, Inc

Attn: W. Coons

4775 Indian School NE

Suite 300

Albuquerque, NM 87110-3927

$\mathrm{RE} / \mathrm{SPEC}$, Inc .

Attn: J.L. Ratigan

PO Box 725

Rapid City, SD 57709

Southwest Research Institute (2)

Center for Nuclear Waste

Regulatory Analysis

Attn: P.K. Nair

6220 Culebra Road

San Antonio, TX 78228-0510

SAIC

Attn: D.C. Royer

101 Convention Center Dr.

Las Vegas, NV 89109

SAIC

Attn: H.R. Pratt

10260 Campus Point Dr.

San Diego, CA 92121 
SAIC (2)

Attn: M. Davis

2109 Air Park Rd. SE

Albuquerque, NM 87106

Tech Reps Inc. (3)

Attn: J. Chapman

C. Crawford

T. Peterson

5000 Marble NE

Suite 222

Albuquerque, NM 87110

TRW Environmental Safety Systems

Attn: L. Wildman

2650 Park Tower Dr.

Suite 1300

Vienna, VA 22180-7306

Waterways Experiment Station (10)

Attn: L.D. Wakeley

3909 Halls Ferry Rd.

Vicksburg, MS 39180-6199

Westinghouse Electric Corporation (5)

Attn: Library

C. Conway

C. Cox

L. Fitch

R. Kehrman

PO Box 2078

Carlsbad, NM 88221

Westinghouse-Savannah River

Technology Center (4)

Attn: N. Bibler

J.R. Harbour

M.J. Plodinec

G.G. Wicks

Aiken, SC 29802

\section{National Academy of Sciences, WIPP Panel}

Howard Adler

Oak Ridge Associated Universities

Medical Sciences Division

PO Box 117

Oak Ridge, TN 37831-0117

Ina Alterman

Board on Radioactive

Waste Managemerit, GF456

2101 Constitution Ave.

Washington, DC 20418
John D. Bredehoeft

Western Region Hydrologist

Water Resources Division

US Geological Survey

(M/S 439)

345 Middlefield Road

Menlo Park, CA 94025

Fred M. Ernsberger

250 01d Mill Road

Pittsburgh, PA 15238

Rodney C. Ewing

Department of Geology

University of New Mexico

Albuquerque, NM 87131

Charles Fairhurst, Chairman

Department of Civil and

Mineral Engineering

University of Minnesota

500 Pillsbury Dr. SE

Minneapolis, MN 55455-0220

B. John Garrick

PLG Incorporated

4590 MacArthur Blvd.

Suite 400

Newport Beach, CA 92660-2027

Leonard F. Konikow

US Geological Survey

431 National Center

Reston, VA 22092

Peter B. Myers

National Academy of Sciences

Board on Radioactive

Waste Management

2101 Constitution Ave.

Washington, DC 20418

Jeremiah O'Driscoll

Jody Incorporated

505 Valley Hill Drive

Atlanta, GA 30350

Christopher G. Whipple

Clement International

160 Spear St.

Suite 1380

San Francisco, CA 94105 


\section{Individuals}

P. Drez

8816 Cherry Hills Rd. NE

Albuquerque, NM 87111

D.W. Powers

Star Route Box 87

Anthony, TX 79821

\section{Universities}

University of New Mexico

Geology Department

Attn: Library

Albuquerque, NM 87131

University of Washington

College of Ocean

and Fishery Sciences

Attn: G.R.Heath

583 Henderson Hall

Seattle, WA 98195

\section{Libraries}

Thomas Brannigan Library

Attn: D. Dresp

106 W. Hadley St.

Las Cruces, NM 88001

Government Publications Department

Zimmerman Library

University of New Mexico

Albuquerque, NM 87131

Hobbs Public Library

Attn: $M$. Lewis

509 N. Ship St.

Hobbs, NM 88248

New Mexico Junior College

Pannell Library

Attn: R. Hill

Lovington Highway

Hobbs, NM 88240

New Mexico State Library

Attn: N. McCallan

325 Don Gaspar

Santa Fe, NM 87503

New Mexico Tech

Martin Speere Memorial Library

Campus Street

Socorro, NM 87810
WIPP Public Reading Room

Carlsbad Public Library

Attn: Director

$101 \mathrm{~S}$. Halagueno St.

Carlsbad, NM 88220

\section{Foreign Addresses}

Studiecentrum Voor Kernenergie

Centre D'Energie Nucleaire

Attn: A. Bonne

SCK/CEN Boeretang 200

B-2400 Mo1, BELGIUM

Atomic Energy of Canada, Ltd. (3)

Whiteshel1 Research Estab.

Attn: B. Goodwin

M. Stevens

D. Wushke

Pinewa, Manitoba, CANADA ROE 1LO

Francois Chenevier (2)

ANDRA

Route du Panorama Robert Schumann B. P. 38

92266 Fontenay-aux-Roses, Cedex

FRANCE

Jean-Pierre 0livier

OECD Nuclear Energy Agency

Division of Radiation Protection and Waste Management

38, Boulevard Suchet

75016 Paris, FRANCE

Claude Sombret

Centre D'Etudes Nucleaires

De La Vallee Rhone

CEN/VALRHO

S.D.H.A. B.P. 171

30205 Bagnols-Sur-Ceze, FRANCE

Gesellschaft fur Reaktorsicherheit

(GRS) (2)

Attn: B. Baltes

W. Muller

Schwertnergasse 1

D-5000 Cologne, GERMANY

Bundesanstalt fur Geowissenschaften und Rohstoffe

Attn: $M$. Langer

Postfach 510153

3000 Hanover 51, GERMANY 
Bundesministerium fur Forschung und Technologie

Postfach 200706

5300 Bonn 2, GERMANY

Institut fur Tieflagerung (2)

Attn: K. Kuhn

Theodor-Heuss-Strasse 4

D-3300 Braunschweig, GERMANY

Physikalisch-Technische Bundesanstalt Attn: P. Brenneke

Postfach 3345

D-3300 Braunschweig, GERMANY

Shingo Tashiro

Japan Atomic Energy Research Inst. Tokai-Mura, Ibaraki-Ken, 319-11

JAPAN

Netherlands Energy Research

Foundation ECN

Attn: L.H. Vons

3 Westerduinweg

PO Box 1

1755 ZG Petten, THE NETHERLANDS

Svensk Karnbransleforsorjning $A B$

Attn: F. Karlsson

Project KBS

Karnbranslesakerhet

Box 5864

10248 Stockholm, SWEDEN

Nationale Genossenschaft für die

Lagerung radioaktiver Abfälle (2)

Attn: S. Vomvoris

P. Zuidema

Hardstrasse 73

$\mathrm{CH}-5430$ Wettingen, SWITZERLAND

AEA Technology

Attn: J.H. Rees

D5W/29 Culham Laboratory

Abington, Oxfordshire OX14 3DB

UNITED KINGDOM

AEA Technology

Attn: W.R. Rodwell

044/A31 Winfrith Technical Centre

Dorchester, Dorset DT2 8DH

UNITED KINGDOM
AEA Technology

Attn: J.E. Tinson

B4244 Harwell Laboratory

Didcot, Oxfordshire OX11 ORA

UNITED KINGDOM

D.R. Knowles

British Nuclear Fuels, plc

Risley, Warrington, Cheshire WA3 6AS

1002607 UNITED KINGDOM

\section{Internal}

$\begin{array}{ll}1502 & \text { J.C. Cummings } \\ 6000 & \text { D.L. Hartley } \\ 6119 & \text { E.D. Gorham } \\ 6119 & \text { Staff (14) } \\ 6121 & \text { J.R. Tillerson } \\ 6121 & \text { Staff (7) } \\ 6300 & \text { D.E. E1lis } \\ 6302 & \text { L.E. Shephard } \\ 6303 & \text { S.Y. Pickering } \\ 6303 & \text { W.D. Weart } \\ 6305 & \text { S.A. Goldstein } \\ 6306 & \text { A.L. Stevens } \\ 6342 & \text { D.R. Anderson } \\ 6342 & \text { Staff (20) } \\ 6343 & \text { S.A. Orre11 } \\ 6343 & \text { Staff (2) } \\ 6345 & \text { R.C. Lincoln } \\ 6345 & \text { Staff (9) } \\ 6347 & \text { D.R. Schafer } \\ 6348 & \text { J.T. Holmes } \\ 6351 & \text { R.E. Thompson } \\ 6352 & \text { D.P. Garber } \\ 6352 & \text { S.E. Sharpton } \\ 6352 & \text { WIPP Central Files (10) } \\ 7141 & \text { Technical Library (5) } \\ 7151 & \text { Technical Publications } \\ 7613-2 & \text { Document Processing for } \\ & \text { DoE/OSTI (10) } \\ 8523-2 & \text { Central Technical Files }\end{array}$



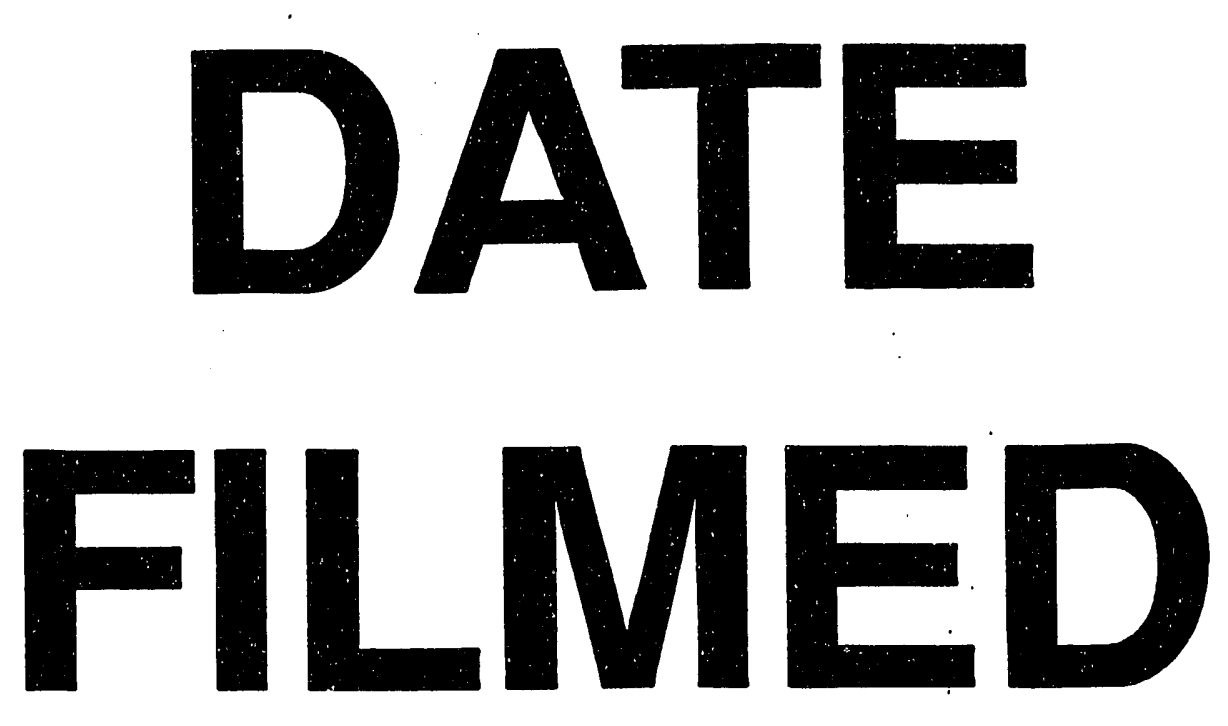

$9 / 28 / 93$
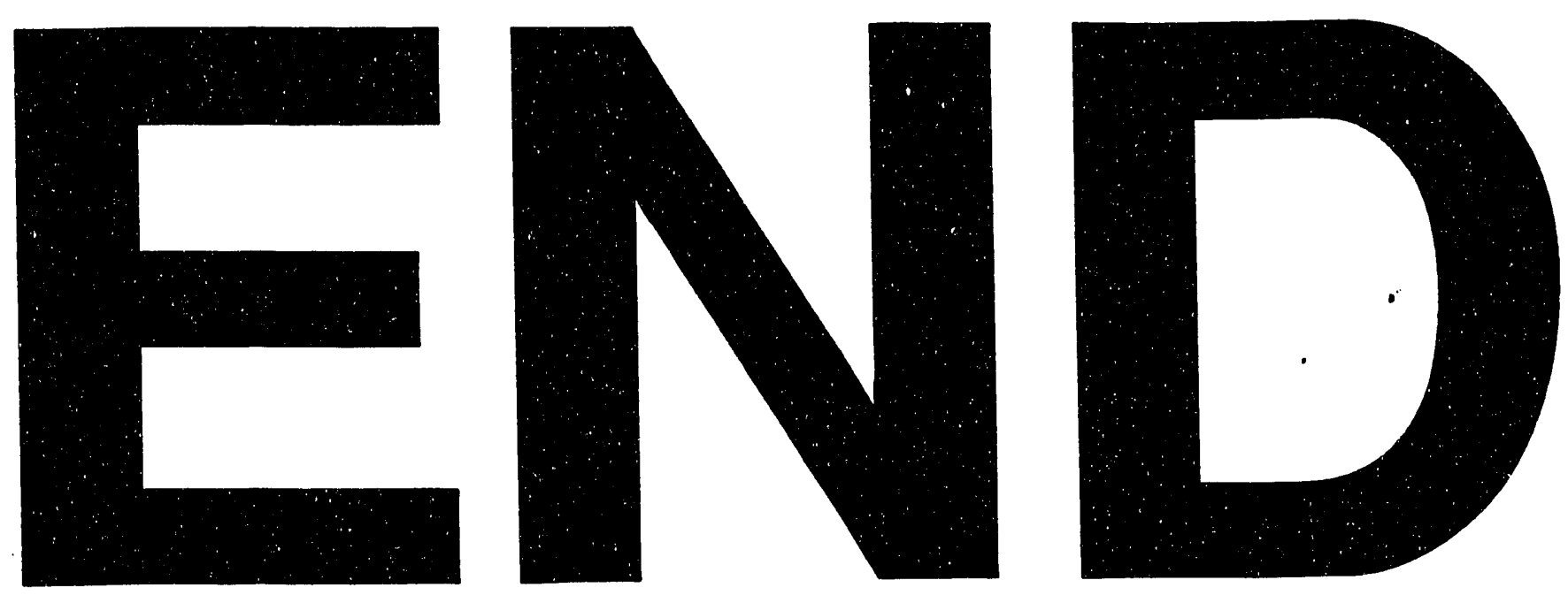
